NBER WORKING PAPER SERIES

\title{
WHAT HAPPENS WHEN WE RANDOMLY ASSIGN CHILDREN TO FAMILIES?
}

\author{
Bruce Sacerdote \\ Working Paper 10894 \\ http://www.nber.org/papers/w10894 \\ NATIONAL BUREAU OF ECONOMIC RESEARCH \\ 1050 Massachusetts Avenue \\ Cambridge, MA 02138 \\ November 2004
}

I thank Holt International Children's Services and particularly Laura Hofer for her help in gathering data and information on international adoptions. The National Science Foundation provided generous funding for the entire project including the data collection. I thank Anne Ladenburger, Abigail Ridgeway, and Ariel SternMarkowitz for tireless research assistance and valuable suggestions. Seminar participants at NBER Summer Institute, Syracuse, Cornell, Case-Western, Brigham Young University and elsewhere contributed helpful comments. The views expressed herein are those of the author(s) and not necessarily those of the National Bureau of Economic Research.

(C) 2004 by Bruce Sacerdote. All rights reserved. Short sections of text, not to exceed two paragraphs, may be quoted without explicit permission provided that full credit, including $\odot$ notice, is given to the source. 
What Happens When We Randomly Assign Children to Families?

Bruce Sacerdote

NBER Working Paper No. 10894

November 2004

JEL No. J0, I2

\begin{abstract}
$\underline{\text { ABSTRACT }}$
I use a new data set of Korean-American adoptees who, as infants, were randomly assigned to families in the U.S. I examine the treatment effects from being assigned to a high income family, a high education family or a family with four or more children. I calculate the transmission of income, education and health characteristics from adoptive parents to adoptees. I then compare these coefficients of transmission to the analogous coefficients for biological children in the same families, and to children raised by their biological parents in other data sets. Having a college educated mother increases an adoptee's probability of graduating from college by 7 percentage points, but raises a biological child's probability of graduating from college by 26 percentage points. In contrast, transmission of drinking and smoking behavior from parents to children is as strong for adoptees as for non-adoptees. For height, obesity, and income, transmission coefficients are significantly higher for non-adoptees than for adoptees. In this sample, sibling gender composition does not appear to affect adoptee outcomes nor does the mix of adoptee siblings versus biological siblings.

Bruce Sacerdote

6106 Rockefeller Hall

Department of Economics

Dartmouth College

Hanover, NH 03755-3514

and NBER

bruce.sacerdote@dartmouth.edu
\end{abstract}




\section{Introduction}

Social scientists have long been interested in the effects of family and neighborhood environment on children's outcomes and the transmission of parental characteristics to children. For example, Black, Devereux and Salvanes [2003] show that exogenous shocks to mother's education have small effects on children's educational attainment, while Currie and Moretti [2003] show that mother's education has a causal link to children's health. In a well known experiment Katz. Kling and Liebman [2001] and Ludwig, Duncan and Hirschfield [2001] look at the effects of moving to a different neighborhood on children's educational outcomes, employment and involvement with crime. And there are large literatures that deal with the effects of schools and neighborhoods on children's test scores, educational attainment, income, and health (e.g. Evans Oates and Schwab [1992], Case and Katz [1991], Hanushek, Kain and Rivkin [1998], Hoxby [2000]).

This paper uses adoption in infancy as a form of grand intervention in which children are assigned a particular set of adoptive parents, thereby creating exogenous variation in the family, neighborhood and school environment. The adoptees in the study are Korean-Americans placed by Holt International Children's Services during 1970-1980. The adoptees are randomly assigned to families, conditional on the family being certified by Holt to adopt. Holt uses a queuing (firstcome first-served) policy to assign Korean adoptees to families. I examine the degree to which child's income, educational and health outcomes are affected by the adoptive parents' inputs. ${ }^{1}$

I find that mother's and father's level of education has a modest impact on the adoptees' educational attainment and income. For example, an additional year of mother's education raises the adoptee's years of education by .07 years. This effect is highly statistically significant, but is 
only $1 / 4$ the size of the corresponding effect for non-adoptees (biological children) raised in the same families. My estimated treatment effects for the adoptees are smaller than those found by Björklund Lindahl and Plug [2004], Plug [2004] and Sacerdote [2002], and this difference may be driven by the lack of selection of the Holt adoptees into families. Consistent with Case, Lin and McLanahan [2000], the quality-quantity tradeoff experienced by adoptees is very large. Growing up in a family of four or more children versus a smaller family reduces an adoptee's probability of attending college by 8 percentage points. ${ }^{2}$

The experiment of being adopted into one family versus another is potentially a much larger intervention than the experiments normally contemplated by social scientists. For example, the Moving to Opportunity experiment (Katz, Kling and Liebman [2001] and Kling, Ludwig and Katz [2004]) shifts the complier subjects neighborhoods and schools but generally leaves the family unit intact. And for most MTO subjects the intervention begins in adolescence rather than in infancy as in the case of adoption. Other experiments such as charter school lotteries (Cullen, Jacobs and Levitt [2004], Rouse [1998]) or school redistricting (Nechyba and Vigdor [2003]), create exogenous variation in the school attended by the child. without directly altering the neighborhood or family influences. And some experiments shift the peer group without shifting the school or neighborhood (Hoxby [2000], Angrist and Lang [2002], Sacerdote [2001], Zimmerman [2002], Foster [2003]).

Adoption into a high versus low SES (socio-economic status) family is in some respect the maximum possible intervention since every aspect of the adoptee's life is different. This is both good and bad for the interpretation and use of the estimates produced. On the positive side, I can

\footnotetext{
${ }^{1}$ Economists have recently become interested in looking at the experiment of adoption and Björklund, Lindahl and Plug [2004] is the largest and most comprehensive study to date.

${ }^{2}$ This might be a quality-quantity tradeoff or it might be something unmeasured about the large families of adoptees. Black, Devereaux Salvanes [2004] which instruments for family size would support the second interpretation. In the point estimates, the effect is stronger for adoptees than non-adoptees.
} 
argue that I am measuring an upper bound of the possible effects from policies that seek to improve child's education or income by altering the school, neighborhood or family environment. Under strong assumptions, I can express my results as a percent of the variation in child outcomes that can be attributed to variation in nurture within the sample. ${ }^{3}$ On the negative side, I can not sort out causal pathways by which the parent's SES affects the children. Adoptive parent's income, education, neighborhood and school quality all co-vary in the known ways.

Slightly more than 2 percent of all children in the US live with an adoptive mother and father. Thus there are roughly 1.4 million adoptees under age 18 for whom adoption policy is directly relevant.

A natural question is whether or not adoption studies and mine in particular are relevant for understanding outcomes for non-adoptees. Even though these families are all pre-screened as being eligible to adopt through Holt, there is still a large amount of variation in family income, parental education, and in the outcomes for the children in the families. For example, 20 percent of the adoptive fathers in my sample have completed 12 or fewer years of education. The adoptees in the sample have educational attainment and family income that is only modestly higher than U.S. averages. The mean years of education for the Holt adoptees is 14.75 years versus 14.11 for AsianAmericans in the NLSY and 13.57 for all other subjects in the NLSY. ${ }^{4}$ For the biological children in my sample, I obtain transmission coefficients of education that are similar to those found for children raised by their biological parents in the PSID, Wisconsin Longitudinal Data, and the national registry data for Sweden and Finland.

\footnotetext{
${ }^{3}$ The question of how much environment (nurture) affects outcomes must always be measured relative to the variation in nurture in the data. For example, there is likely an enormous positive effect on family income from moving a child from an orphanage in South Korea to a US family, but I can not measure this effect.

${ }^{4}$ Author's calculations from the National Longitudinal Survey of Youth 1979. I use the 1979 sample weights to approximate US averages.
} 
The adoptees in the sample have roughly .9 fewer years of education than the non-adoptees in the same families. But there is still substantial overlap in the distribution of outcomes for adoptees and non-adoptees. The fact that all of the adoptees are Korean American may influence some of the findings and I address this point several times in discussing the results.

Is transmission of education, income and health fundamentally different for US adoptees versus all other US children? This question is ultimately impossible to answer. But in trying to apply lessons learned from adoption data to children in general, I am reassured by the fact that the adoptees in the sample resemble the population of non-adoptive children both in their outcomes and in their nurturing parents' background. 
A Brief History of Holt and Korean-American Adoption and the Assignment Process

Harry and Bertha Holt pioneered international adoption in Seoul, Korea in 1955. The Holts had built a fortune in lumber and farming in Oregon and were so moved by the plight of Korean war orphans that they lobbied Congress for a special act to adopt eight of them. When they returned home with their new children, they discovered that many other Americans also wished to adopt from Korea.

Since 1955 over 100,000 Korean children have been adopted into US families, and the agency which grew out of the Holt's initial work, now called Holt International Children's Services, has been involved in 30 to 40 percent of these adoptions. Holt currently places about 300 Korean adoptees per year, and hundreds more from China and from programs in Bulgaria, Ecuador, Guatemala, Hong Kong, India, , Mongolia, Philippines, Romania, Thailand, and Vietnam.

The process of adopting through Holt's Korea program takes roughly 12-18 months from initial application to bringing home the adoptee. The major steps include filing an application, participating in the home study assessment, attending adoption education classes, passing the criminal background check, being matched with an adoptee, the adoptee flying to the U.S., and legally adopting the child in family court. This is an extensive and thorough process requiring numerous meetings with adoption agency officials and numerous exchanges of documents. In part due to US and South Korean law, adoptive parents must meet several criteria including a minimum family income and must be married for three years or longer.

Holt Children's Services of Korea, a separate organization from Holt International Children's Services, is in charge of matching children with qualified adoptive parents and does this in a way which randomizes children into families. Within the Korea program and conditional upon 
being qualified to adopt, children are matched to families on a first come, first served basis. Parents are not given the opportunity to specify gender or anything else about their future adoptee. The one exception to this rule is that families with all boys or all girls are allowed to request a child of the opposite gender. In practice, those who are eligible to request girls frequently do so. This does not present a problem for this study since I condition on adoptee gender in every specification. The only other opportunity parents have to specify a preference is to indicate that they would be open to adopting a child with special needs or a disability. I exclude all such adoptions from the sample.

Thus it is the timing of when applications are completed that creates the matching of parents to children, rather than any matching of parent and child characteristics. I provide evidence below that the child's weight in infancy and other pre-adoption characteristics are uncorrelated with adoptive parent characteristics such as family income, parental education etc.

\section{Relation to the Adoption Literature}

I follow the empirical approach of recent papers in economics including Björklund, Lindahl and Plug [2004], Sacerdote [2002], Das and Sjogren [2002], and Plug and Vijverberg [2003] in that I regress child outcomes on parent inputs, treating the adoptive parents as randomly assigned. The paper differs from the existing literature in several ways: First and most importantly the data set is constructed explicitly so that I have true random assignment of children to families. Second, I have a number of outcomes that were not available to me or other economists in prior studies, such as drinking, smoking, asthma, obesity and selectivity of the college attended.

Third in addition to calculating straight transmission coefficients (from parents to children) for income and education, I take a broad approach and examine the effects of family size, birth 
order, parental age and family gender composition. This allows me to test for effects of family size and sibling gender in a context where the number and gender of siblings is randomly assigned to the child.

There is a large adoption literature outside of economics and it has focused mostly on estimating the heritability of IQ, as in Scarr and Weinberg [1978, 1981], and personality traits as in Loehlin, Horn, and Willerman [1985, 1987, 1994], and Plomin, Defries, and Fulker [1988, 1991, 1997]. I depart from this literature in two ways. First I focus on income, education and health outcomes rather than IQ and personality traits. Second, I use a simple experimental design (random assignment to adoptive family) without imposing the structural models used in the behavioral genetics literature.

A series of papers including Taubman [1988], Behrman and Taubman [1989] and Behrman, Rosenzweig and Taubman [1994] use comparisons of identical and fraternal twins to identify the nature and nurture components of educational attainment and obesity. These papers impose a structural model on the data in order to derive explicit formulae for the variance and covariance of outcomes for the two different types of twins and their offspring. The identification of nature versus nurture components comes from the fact that identical twins share precisely the same genes whereas fraternal twins do not, and from a series of assumptions regarding how much family environment and DNA is shared between siblings, first cousins, second cousins etc. Goldberger [1989] points out a number of limitations to this approach.

\section{Empirical Framework and Interpretation of Transmission Coefficients}

In the results below I regress the adoptee's outcomes on the parent's inputs. Alternatively I compare mean outcomes for treatment groups of adoptees where I form treatment groups on mother's education, or income or family size. I interpret these coefficients (and differences in 
means) as reduced form treatment effects. Assignment to treatment group is random due to Holt's adoption process. All of the adoptees comply with their assigned treatment group. Because of the randomization, I can interpret my estimates as the causal effect of being assigned to a particular type of family. However, within the treatment effect I cannot parse out the extent to which the effect is working through specific inputs such as mother's education, family income or unobserved factors such as school quality, neighborhood quality etc.

In addition to calculating a series of treatment effects, I also measure the transmission of characteristics from parent to child in a case where there is no genetic connection between the parent and child. As an accounting identity, we know that all effects of the parents on the children take place through initial endowments (including genes), through environment (nurture) effects, and through the interaction of the two. ${ }^{5}$ For the transmission of education from mothers to children we might linearize the accounting identity in the following way:

(1) Child's years of education $=\alpha+\beta 0 *$ birth mother's educ $+\beta 1 *$ adoptive or environmental mother's educ $+\beta 2 *$ birth mother's educ*adoptive mother's education $+\varepsilon_{\mathrm{i}}$

The random assignment of adoptees to families ensures that birth mother's education is uncorrelated with adoptive mother's education. Thus we can regress the adoptee's educational attainment on adoptive mother's educational attainment and obtain an estimate of $\beta 1$. Even though birth mother's education and the interaction term are omitted variables, they are orthogonal to the adoptive mother's education and therefore $\beta 1$ is not biased by the omission of the first and third terms in (1).

\footnotetext{
${ }^{5}$ As part of this interaction, initial endowments may themselves cause changes in environment as in Ridley [2003] and Dickens and Flynn [2001].
} 
For the non-adoptees, the birth mother is the environmental mother and so the two measures of mother's education are perfectly correlated. Regressing the non-adoptees educational attainment on mother's education and yields an estimate of $(\beta 0+\beta 1+\beta 2)$.

I compute the ratio of the adoptee and the non-adoptee coefficients which is $\beta 1 /(\beta 0+\beta 1+\beta 2)$. This is an estimate of the percent of transmission of educational attainment that works through the level effect of environmental mother's education. Ideally I would like to give this ratio a broader interpretation, namely the percent of the child's education that is determined by nurture as opposed to nature and infant health (initial endowments). To make this leap requires several very strong assumptions. First I need to assume that there are no interaction effects between initial endowments and family environment, i.e. $\beta 2=0{ }^{6}$

This seems like a dubious assumption on both theoretical and empirical grounds. We know from previous studies including Sacerdote [2001] and Björklund et al [2004] that the transmission coefficient for the non-adoptees (.26) is much higher than for the adoptees (.07). An assumption of no interactions amounts to assuming that the large transmission coefficient for the non-adoptees works almost exclusively through level effects of nature and infant health. This is in fact precisely the assumption made by most behavioral genetics studies of heritability of IQ and other traits (e.g. Loehlin, Horn and Willerman [1987]) and this assumption partially explains the high estimated heritabilities found in the literature.

Second, I would need to make some assumptions about the 80 percent of the variation in child's educational attainment that is not explained by the observed factors. If I further assume that

\footnotetext{
${ }^{6}$ Once I allow interaction effects, then a nature nurture breakdown is non-sensical since the two factors work together and perhaps are even endogenously determined. Again I emphasize that any nurture effects estimated are relative to the
} 
this variation is either uncorrelated with the nature and nurture factors of interest in my decomposition, or has the same nature/nurture breakdown as my observed factors, then I can claim that my ratio $\beta 1 /(\beta 0+\beta 1)$ is indeed the percent of educational attainment determined by family environment.

\section{Data Description}

We collected data on adoptive parents and their children using Holt records and a mail in survey. $^{7}$ The survey asks questions on the children's health, education, and income. We also collected basic demographic outcomes including marital status and number of children. Currently we only have surveys from the parents, but we intend to survey as many of the children as possible to validate the parents' responses. The family background (parental input) variables include parental income at the time of adoption, the education of the mother and father, drinking and smoking behaviors of the mother and father and height and weight for each. We have income as self reported on the surveys and we have income as reported in Holt records.

Parents were eligible for inclusion in the survey if they adopted a child through Holt's Korea program during 1970-1980, making the children ages 23-33 in 2003 when the survey was run. There were roughly 10,000 such families who met this criterion and we sent the survey to a random sample of 3,500 of these families. Our cover letter promised respondents a check for $\$ 50$ and this was paid immediately upon receipt of a completed survey. We received back 1117 surveys for a response rate of 32 percent.

variation within the sample. I don't want to rule out the possibility that huge nurture interventions (moving the child from Korea to the US) have huge effects.

${ }^{7}$ I say we because the effort required extensive work from Holt officers and employees and from a team of research assistants at Dartmouth. 
Appendix Table 1 shows that the non-response pattern is unrelated to any of the parental characteristics that we have from the adoption files. I run an OLS regression of a dummy for responding on parental income, parental education and the adoptee's height and weight at the time of admission to Holt. The coefficients on the right hand side variables are all small and statistically insignificant.

Appendix Table 2 performs a simple test of the random assignment of adoptees to families. I regress pre-treatment variables for the adoptees on pre-treatment variables for the parents. Under the null of randomization of adoptees to families, we should see no relationship between adoptee and parent characteristics. The data are consistent with randomization. Mother's and father's education and income are uncorrelated with the adoptee's height, and weight measured at the child's first contact with Holt.

The survey collects outcomes for up to 5 children in the family. Fortunately, for the purposes of sample size, most families had more than one child, and in many cases families had more than one Holt adoptee from Korea. Table 2 shows a frequency tabulation of family sizes in the sample. Of the roughly 1100 families, 323 have two children, 298 have 3 children, and 214 have four children. Only 60 families have a single child, and that child is of course a Holt adoptee. Eighty five of our families have six or seven children, but unfortunately we only collected information on 5 of the children in these large families. ${ }^{8}$

Table 2 shows the fraction adoptees and fraction girls by family size. In single child families, where there is exactly one Holt adoptee, 78 percent of the adoptees are girls. In families of

\footnotetext{
${ }^{8} \mathrm{We}$ did ask the respondents to include their oldest adoptee through Holt. I failed to anticipate so many families of more than 5 children.
} 
two children, 80 percent of the children are adoptees and 63 percent are girls. In the larger families, 55-60 percent of the children are adoptees and about 55 percent are girls.

We have data for both adoptees and non-adoptees in the family. We collected information on the non-adoptees (biological children of the parents) so that we could compare treatment effects and transmission coefficients across the two groups. We use all children in the family to calculate family size and to calculate gender ratios and percent adopted in each family. For the subsequent analysis of adoptees, we keep only Korean adoptees through Holt. We drop the small number of adoptees under 18 since it is very unlikely that their schooling is complete or that we have useful income data for them. Seven percent of the final sample is under age 21, and in all of our regressions we include a set of age dummies to allow for the fact that most of our outcomes including income, educational attainment and marital status vary by age.

Table 1 shows mean outcomes at the child level (as opposed to the family level). Thirty percent of the adoptees are male versus 61 percent of the biological children. The adoptive families clearly have more than the U.S. population average of boys among their biological children, which may indicates that some families might be adopting in part to diversify away from boys. The adoptees are on average six years younger than the non-adoptees. The adoptees' average age at arrival in the U.S. is 1.7 years, with 28 percent of the adoptees being over age 1 at arrival. Below I test whether arrival age in this sample matters for outcomes and find no evidence that it does.

Forty eight percent of the adoptees have four years of college versus 65 percent for the nonadoptees. Conditional on graduating from a college for which we have U.S. News rankings and data, the adoptees graduate from colleges with roughly similar SAT scores and acceptance rates as the non-adoptees. The non-adoptees graduate from schools with a $75^{\text {th }}$ percentile of SAT scores 
that is 13 points higher than the schools of the adoptees. The survey measure of family income is much higher for the non-adoptees than for the adoptees: $\$ 61,000$ per year versus $\$ 42,000$ per year. But this huge difference narrows to $\$ 1,600$ when I control for age, education, and gender.

The adoptees are less likely to be married, but this is partially an age effect. Thirty four percent of the non-adoptees are classified as overweight (have a Body Mass Index $>25$ ) versus 24 percent of the adoptees. This could be correlated with the fact that the adoptees are all Korean and most of the non-adoptees are white, though I do not offer any theory as to why obesity should vary by race.

Twenty three percent of the adoptees smoke versus thirty two percent of the non-adoptees. Reported smoking rates among the adoptive parents are incredibly low at 3 percent for the adoptive mothers (when weighted at the child level not the family level). This could indicate that people who want to adopt or who are approved to adopt are unlikely to be smokers, or that the parents have learned to not admit to smoking in an adoption related survey.

Figure 1 shows the steep negative relationship between family size and the adoptees' probability of graduating from college. Adoptees who are randomly assigned into a single child family have about a 55 percent probability of college graduation versus a 35 percent graduation rate for adoptees assigned into a seven child family. The negative slope is less steep for the nonadoptees. The negative effects of family size on education (and the difference in slopes) remain quite strong even after I control for other family characteristics (see below), though Black Devereaux Salvanes [2004] would suggest that much of the relationship is driven by unobservables about the family. 
Figure 2 shows how the adoptees and non-adoptees mean years of education vary with mother's education. The relationship is clearly positive for both groups, but the slope is much less steep for the adoptees than for the non-adoptees. In other words, the adoptees benefit much less from additional years of mother's schooling than do the non-adoptees. At lower levels of mother's education (moving the mother from 11 to 12 years completed), both groups benefit enormously from additional years of mother's schooling. But at 13 years of mother's education, the slope flattens out for the adoptees.

This pattern of differing slopes for the two groups is more extreme when we look at income. Figure 3 shows mean family income for the adoptees and non-adoptees at each level of parental income. The adoptee's income appears to have almost no relationship to parental income.

Results

In Table 3, I show transmission coefficients from parents to children for a variety of outcomes. In this table each coefficient is from a separate univariate regression in which I regress the child's outcome on the same outcome for the mother or parents. Very similar results obtain when I use the father's outcome instead of the mother's (not shown). More importantly very similar results are obtained when I measure these transmission coefficients controlling for other parental background information, and child age and gender. See, for example, Tables 4 and 5.

In the first row of Table 3, I regress the child's years of education on the mother's. For the non-adoptees I find a coefficient of .30. The coefficient of transmission for the adoptees is a much smaller but still highly statistically significant .07. Relative to Björklund et al, I find a slightly larger coefficient for the non-adoptees and a smaller coefficient for the adoptees. In my sample, roughly 23 percent of the transmission of educational attainment can be assigned to level effects of 
environmental mother's education. In the Björklund et al's, this number is closer to 50 percent. One possible explanation for the difference may be positive selection of adoptees into families in the Swedish data. In fact when I run the same regression for non-Holt adoptees in the same families (where there is no random assignment) I find a much higher transmission coefficient of .16 which is close to the Björklund Lindahl Plug estimate.

Results using a dummy variable for graduation from college are similar to those using years of education attainment. The transmission coefficient for the adoptees is .07 versus .26 for the nonadoptees. This indicates that 27 percent of the transmission coefficient for non-adoptees works through level effects associated with the mother's college status.

Health outcomes show a very different pattern of transmission than do educational outcomes. Unsurprisingly, parents transmit their height to their biological children much more strongly than to their adoptive children. The relevant coefficients are .46 and .05 . Interestingly, body mass index is also transmitted much more strongly to non-adoptees than to adoptees. ${ }^{9}$ The transmission coefficient for the non-adoptees is .24 versus .02 for the adoptees. This latter finding could be interpreted in one of several ways. It may be that BMI and obesity have a huge genetic component which accounts for the much stronger parent to non-adoptee correlation that we see. Or it may be the interaction between having genes for obesity and having parents who eat a lot that accounts for the strong transmission to non-adoptees.

A third related possibility is that because the Korean American adoptees do not necessarily resemble the parents physically, the adoptees do not take cues from the parent's eating and weight in setting their own eating and exercise habits. To investigate whether interactions between parent and

\footnotetext{
${ }^{9}$ Vogler et. al. [1995] have the same finding in a sample that is mostly caucasian adoptees.
} 
child race are relevant in determining these transmission coefficients, I ran the same regression for 240 non-Holt adoptees. I do not have race for these adoptees, but I do know birth country. Interestingly, I find the same low transmission coefficient of BMI from parents to adoptees (a statistically insignificant .02) when I look at the non-Holt adoptees. This evidence plus Vogler et al [1995] suggest that the result is true for adoptees in general, and not just Korean adoptees.

Two final outcomes of interest are dummy variables for drinking and smoking. The coefficient of transmission for smoking is just as high for the adoptees as for the non-adoptees. Unfortunately this is not measured with great precision because so few of the parents smoke. For drinking, the coefficient for the adoptees is .21 which is 68 percent as large as the coefficient for the non-adoptees of .31 . Overall, it appears that the level effects of family environment are a much bigger component of transmission for drinking and smoking than for years of education. ${ }^{10}$

In Appendix 3, I switch from looking at transmission coefficients for these outcomes to looking at the r-squareds in regressions of child outcomes on all the observed family background characteristics. Each cell in the table reports the r-squared from a regression of the outcome on mother's and father's years of education, college status, smoking and drinking status, height, weight, and obesity and overweight status. I also include as regressors family income and number of children in the family.

For the non-adoptees, I can explain 19 percent of the variation in years of education using the observables about the parents. For the adoptees, I can explain 5 percent of the variation, making the ratio of adoptee r-squared to non-adoptee r-squared 28 percent. This is similar to ratio of adoptee to non-adoptee transmission coefficients of 23 percent shown in Table 3 . The r-squared 
ratios for height, body mass index and smoking and drinking also show a similar pattern to that of Table 3. The percentage of adoptees' variation in smoking that can be explained is 69 percent as large as the percentage of non-adoptees variation in smoking. In contrast a much smaller percentage of variation in height and BMI can be explained for adoptees than for non-adoptees.

Figure 4 shows a scatterplot of the results in Tables 3. I graph the non-adoptee coefficient against the adoptee coefficient for nine different outcomes. The 45 degree line represents outcomes for which the two transmission coefficients are equal. Eight of the nine outcomes fall above the 45 degree line meaning that the non-adoptee coefficient is larger. The outcome closest to the 45 degree line is drinking, indicating that for these outcomes, adoptees and non-adoptees are similar in the degree to which they acquire their parent's habits. Obesity is also near the 45 degree line, but only 6 percent of children are classified as obese. BMI and overweight status have much more variation and are significantly above the 45 degree line.

Table 3A shows how my transmission coefficients for adoptees and biological children compare with coefficients found in other data sets by other authors. The first four rows of the table are for four different samples of biological children. Coefficients of transmission of education to biological children in the Holt sample are close to those Björklund et al find in the Swedish data, ie $.25-.30$. Transmission of education in the NLSY is significantly higher at .40. My income transmission coefficient of .16 is half of the $.25-.30$ found in the Swedish data and the PSID. The lower income transmission in my sample is quite possibly driven by higher measurement error in my income survey question.

\footnotetext{
${ }^{10}$ Again, by "level effects" I mean the coefficient on environmental mother's outcome in equation (1), as opposed to the coefficient on biological mother's outcome or the coefficient on the interaction term.
} 
For the adoptees, I estimate transmission coefficients of education that are significantly smaller than coefficients found in the NLSY (my calculations) and Wisconsin Longitudinal Survey (Plug [2004]). I attribute much of this difference to the random assignment of adoptees in the Holt sample.

In Table 3B I approach the transmission via nurture question in a slightly different way. I ask how much children resemble their adoptive or biological siblings, as opposed to their parents. I form pairs of biological siblings and pairs of adoptive siblings. I regress the younger child's outcome on the older child's outcome. For education, I find very similar coefficients as those found using parents: a coefficient of .09 for adoptive siblings and .29 for biological siblings. The connection in drinking behavior is equally strong between pairs of adoptive siblings and pairs of biological siblings. The body mass index of two adoptive siblings is uncorrelated. The only notable difference in results is with regard to income. Sibling's income has a coefficient of .16 for adoptive pairs and .29 for biological pairs.

Table 4 proceeds to regressions of educational outcomes on parent characteristics. Each column is a separate regression and I pool the data for adoptees and non-adoptees. The base category is always the adoptees. For the parental characteristics I include interactions between parental characteristics and a dummy for being a biological child of the parent. (The slope for the non-adoptees is the sum of the baseline coefficient plus the interaction term.) The regressions include, but do not report, age dummies and a dummy for biological child. ${ }^{11}$

Column (1) uses years of education as the outcome. In the first two rows I repeat a key result from Table 3, namely that the coefficient on mother's education is .07 for the adoptees and 
.185 higher for the non-adoptees. Each additional child in the family reduces an adoptee's expected years of education by .12 years and the effect is highly statistically significant. However, for nonadoptees, the slope on number of children is only -.023 instead of -.12 . The difference between these two coefficients is not statistically significant, though economically it is very significant. The large difference in slopes is consisent with Case, I-Fen Lin and McLanahan's [2000] result that adoptees in blended families experience more of a resource constraint.

The coefficient on number of siblings for the non-adoptees is significantly smaller than the coefficient of -.28 for women in the PSID in Case and Butcher [1994] and the -.09 OLS coefficient in the Norwegian data in Black et al [2004]. One explanation for the difference is that there are more unobserved differences between small and large families in general than between the small and large families in my sample. This seems possible given that my families have all been approved to adopt by Holt.

Log of parental income is not statistically significant in predicting child's years of education, which may be a statement about the measurement error in my parental income variable. The male adoptees have significantly lower educational attainment than the female adoptees, with a coefficient of -.57 years on the dummy for male. The gender effect for the non-adoptees is roughly 0 years, adding the -.57 baseline effect and .55 on the interaction of male and biological child.

Being the oldest child in the family raises an adoptee's educational attainment by .24 years and this effect is statistically significant at the 10 percent level. Non-adoptees are helped even more by being the oldest, but the difference in coefficients for the two groups is not statistically significant. One might think that parental age would have a significant effect on the outcomes for

\footnotetext{
${ }^{11}$ I suppress the latter to avoid confusion. The intercept for biological children is generally negative, but that's because
} 
both groups of children, but I do not find evidence for this effect. For the adoptees the effect of mother's age minus adoptee's age is -.001 and is statistically insignificant.

Column (2) shows that similar results obtain when I use father's education rather than mother's. When I include both father's and mother's education, both inputs matter and the coefficients add up to roughly the coefficient on mother's education (results not shown).

Columns (3) and (4) show that controlling for other characteristics, mother's college status has large effects on the probability that the adoptee graduates college and graduates from a US News ranked college. Adoptees with a college educated mother are 9 percentage points more likely to obtain a college degree themselves, relative to adoptees whose mothers do not have four years of college. This is an 18 percent effect at the means. Adoptees with a college educated mother are also 9 percentage points more likely to obtain a degree from a US News ranked college versus adoptees whose mother does not have four years of college. This is a 26 percent effect at the means.

Conditional on attending a US News listed college, mother's and father's education and family income do not have a statistically significant effect on the selectivity of the college attended. Doubling family income is associated with the adoptee attending a school that has SAT scores (measured at the $75^{\text {th }}$ percentile) that are 15 points higher. This is roughly .14 standard deviations higher in the distribution of $75^{\text {th }}$ SAT percentile across schools.

Column (6) switches the dependent variable to the log of the child's family income. Parental income and mother's college status have virtually no effect on the adoptee's income. In contrast the 
transmission coefficient of income for the non-adoptees, controlling for other parental characteristics is .18. As mentioned above, this is lower than results for than the .30 coefficient typically found for a single year of earnings in the PSID (Solon [1999]) and the .29 I find in the NLSY. The difference could be driven by the restriction of range among Holt families, or by higher measurement error in my survey.

Table 5 examines treatment effects of parent characteristics on several health outcomes including smoking, drinking, and obesity. The key results in Table 5 are similar to those from the univariate regressions in Table 4. Adoptees experience a large treatment effect from their mother's drinking and smoking behavior, but there is little influence of mother's body mass index on the adoptee's BMI or obesity. In column (1), adoptive mother's drinking raises the adoptee's probability of drinking by 19 percent. The effect for the non-adoptees is 26 percent and the difference between the coefficients is not significant. Male adoptees are more likely to drink than female adoptees and each additional year of mother's education raises the adoptee's probability of drinking by 1.1 percent.

The effects for smoking in column (2) show a somewhat similar pattern though the coefficients are smaller and not statistically significant. Mother's smoking raises the adoptee's probability of smoking by 11 percent, and the effect for the non-adoptees is not statistically significantly different.

The effects for BMI and obesity are quite the opposite. Mother's BMI, overweight status and obesity status have a huge effect for her biological children but very little effect for the adoptees. If the mother is classified as overweight, the non-adoptees are 19 percent more likely to be overweight whereas the non-adoptees are .2 percent more likely to be overweight. 
Table 6 asks whether the mix of adoptees and non-adoptees in the family affects the adoptees' outcomes. I form dummy variables for three separate categories of adoptees: 1) the child is the only adoptee in the family, 2) the child is an adoptee in a family with multiple adoptees and one or more biological children, and 3) the child is an adoptee in a family with multiple adoptees and no biological children. The base category for the coefficients are the biological children and the regressions include a separate intercept for biological children, age dummies, family size dummies, mother's education, and family income. Both the point estimates and the standard errors indicate that the outcomes for adoptees do not vary significantly with the mix of adoptees and non-adoptees.

Appendix Table 5 explores whether the estimated transmission coefficients differ by adoptee gender. ${ }^{12}$ I limit the sample to the adoptees and add interaction terms to allow the male adoptees to have a separate slope on mother's education, mother's college status, parental income, and mother's body mass index. The outcomes considered are years of education, graduating from a US News ranked college, drinking, smoking, and BMI. In no case do we find that the male and female adoptees have coefficients that are statistically significantly different. However, the slopes are estimated with enough imprecision that it in most cases it is also difficult to reject a sizeable difference in slopes.

Appendix Table 6 asks whether the gender mix in the family affects the adoptee's outcomes. Again I limit the sample to the adoptees. My right hand side variables of interest are the fraction of girls in the family, whether any of the adoptee's siblings are girls and whether any of the adoptee's siblings are boys. I try running the regressions separately for boys and girls. I do not find any evidence of gender mix effects, but again the standard errors are large enough that I cannot say 
much more than this. Finally in Appendix 7 and in a large series of specifications not reported, I ask whether the child's age at adoption affects outcomes. The short answer is that I cannot find any evidence that within this sample age at adoption matters for educational attainment, income, obesity or drinking. ${ }^{13}$

\section{Conclusion}

In this paper, I examine a sample of Korean-American adoptees who in infancy were randomly assigned to families. Being assigned to a high education family has economically meaningful treatment effects for these adoptees. Adoptees are 9 percent more likely to have four years of college if their mothers do. Each additional year of mother's educational attainment raises the adoptee's educational attainment by .07 years. But the effects for adoptees are modest when compared to corresponding effects for non-adoptees. The transmission of educational attainment and college status to adoptees is roughly 25 percent as large as the transmission of educational attainment and college status to non-adoptees. Thus, for educational outcomes, the level effects of parental education are quite important, but only about one quarter of the story.

Health outcomes show a very different pattern. Parents appear to transmit drinking and smoking behavior to adoptees and non-adoptees at nearly the same rate. If a mother drinks, the adoptee is 19 percent more likely to do so, and if the mother smokes, the adoptee is 11 percent more likely to smoke. The transmission of drinking to non-adoptees is larger in the point estimate but not statistically significantly different than transmission for the adoptees. Thus parents may be equally good at transmitting certain health habits to their children, regardless of any genetic connection.

\footnotetext{
${ }^{12}$ My interest here is in part due to the fact that many of the Moving to Opportunity effects differ greatly by youth's gender Kling, Ludwig and Katz [2004].

${ }^{13}$ It seems logical that it would matter, but there is no strong evidence of the effect in this sample.
} 
For height and obesity, there is strong transmission from parents to their biological children and almost no transmission of these outcomes to adoptees. For example, the transmission coefficient on body mass index is .02 for adoptees and .23 for non-adoptees. The results for body mass index are suggestive of a big role for genes in determining obesity. A model which emphasizes the interaction between genes and environment is one plausible way to explain this. Certain people may have a genetic predisposition towards obesity, and when they are put in a high calorie and/or low exercise environment, they have high BMIs. The random assignment of adoptees to families means that children with obesity promoting genes are not disproportionately likely to end up in an obesity promoting family environment.

The largest treatment effects for the adoptees are either caused by or strongly correlated with the number of children in the family. Each additional child added to the family is associated with a .12 year decrease in the adoptee's educational attainment and a 2.5 percent reduction in the probability of attending college. These large effects from family size may imply that there is a quality quantity tradeoff that is particularly steep for adoptees, relative to non-adoptees. Or, the family size effects may be picking up important unobserved difference between large and small adoptive families.

I also investigated the influences of family structure (number of adoptees versus nonadoptees) and gender composition on adoptee outcomes. I do not find any effects of family structure on education, earnings or obesity. Nor did I find effects from the gender mix in the family or the age at adoption. However, all of these non-results are measured with imprecision.

Overall, this study yields several useful conclusions. First, in a case with random assignment of children to families, family size is still negatively correlated with education and 
income. Second, there is a strong level effect of family environment on child education and income. However transmission of education and income for adoptees is much less strong than for non-adoptees. Hence, by definition, either initial endowments or the interaction between family environment and initial endowments must be driving a large portion of the transmission of income and education to children. Smoking and drinking habits are transmitted almost equally strongly to adoptees and non-adoptees. Perhaps most interesting is the fact that parents do not transmit a tendency for obesity to their adoptees.

Random assignment via adoption is a form of grand experiment that will not be reproduced in policies designed to aid children in general. But for many policies, these data trace out an upper bound for the effects that can be achieved via shifts in family income, or neighborhood quality, or schools. I hope that the treatment effects observed here will guide other social scientists in understanding what determines child outcomes and the possible scope for policy intervention. 


\section{References}

Altonji, Joseph G. and Thomas A. Dunn, "Relationships Among the Family Incomes and Labor Market Outcomes of Relatives," Research in Labor Economics, 12 (1991), 269-310.

Angrist, Joshua D. and Kevin Lang, "How Important are Classroom Peer Effects? Evidence from Boston's Metco Program," National Bureau of Economic Research Working Paper No. 9263, Oct 2002.

Ashenfelter, Orley, and Alan B. Krueger, "Estimates of the Economic Returns to Schooling from a New Sample of Twins," American Economic Review, LXXXIV (1994), 1157-73.

Ashenfelter, Orley, and Cecilia Rouse, "Income, Schooling, and Ability: Evidence from a New Sample of Identical Twins," Quarterly Journal of Economics, CXIII (1998), 253-84.

Behrman, Jere R. and Paul Taubman, "Is Schooling 'Mostly in the Genes'? Nature Nurture Decomposition Using Data on Relatives," Journal of Political Economy, XCVII (1989), 1425-1446.

Behrman, Jere R., Mark R. Rosenzweig and Paul Taubman, "Endowments and the Allocation of Schooling in the Family and in the Marriage Market," Journal of Political Economy, CII (1994), 1131-1174.

Bjorklund Anders and Markus Jantii, "Intergenerational Mobility in Sweden Compared to the United States," American Economic Review, 87 (1997), 377-386.

Bjorklund Anders, Markus Jantii and Gary Solon, "Influences of Nature and Nurture on Earnings Variation: A Report on a Study of Sibling Types in Sweden," in Bowles, Gintis and Osborne (eds. ) Unequal Chances: Family Background and Economic Success, New York: Russell Sage Foundation, 2004a.

Bjorklund, Anders, Mikael Lindahl, Erik Plug, "Intergenerational Effects in Sweden: What Can We Learn from Adoption Data?" Working Paper, Swedish Institute for Social Research, Stockholm University, 2004.

Black, Sandra, Paul J. Devereux and Kjell G. Salvanes, "Why the Apple Doesn't Fall Far: Understanding Intergenerational Transmission of Human Capital," National Bureau of Economic Research Working Paper No. 10066, 2003.

Black, Sandra, Paul J. Devereux and Kjell G. Salvanes, "The More the Merrier? The Effect of Family Composition on Children's Education," National Bureau of Economic Research Working Paper No. 10720, 2004.

Capron, C. and M. Duyme, "Assessment of Effects of Socioeconomic Status on IQ in a Full Cross-fostering Study,” Nature, CCCXL (1969), 552-554.

Cardon, Lon R., David W. Fulker, John C. DeFries, and Robert Plomin, "Multivariate Genetic Analysis of Specific Cognitive Abilities in the Colorado Adoption Project at Age 7," Intelligence, XVI (1992), 383-400. 
Case, Anne C. and Lawrence F. Katz, "The Company You Keep: The Effect of Family and Neighborhood on Disadvantaged Youths," National Bureau of Economic Research Working Paper \# 3705, 1991.

Case, Anne, I-Fen Lin and Sara McLanahan, "How Hungry Is The Selfish Gene?," Economic Journal, 110 (446), pp, 781-804.

Case, Anne and Kristin F. Butcher, "The Effect of Sibling Sex Composition on Women's Education and Earnings," The Quarterly Journal of Economics, v.109 (3), August 1994, pp. 531-563.

Collishaw, S., B. Maughan, and A. Pickles, "Infant Adoption: Pyschosocial Outcomes in Adulthood," Social Psychiatry and Psychiatric Epidemiology, XXXIII (1998), 57-65.

Cullen, Julie Berry, Brian Jacob, and Steven Levitt, “The Impact of School Choice on Student Outcomes: An Analysis of the Chicago Public Schools." Journal of Public Economics (Forthcoming).

Currie, Janet and Enrico Moretti, "Mother's Education and the Intergenerational Transmission of Human Capital: Evidence from College Openings," Quarterly Journal of Economics, CXVIII (4), 2003, pp. $1495-1532$.

Darwin, Charles, On the Origin of Species by Means of Natural Selection, 1859.

Das, Mitali and Tanja Sjogren, "The Intergenerational Link in Income Mobility: Evidence From Adoptions," Economics Letters 75, pp. 55-60.

DeFries, John C., Robert Plomin, and David W. Fulker, Nature and Nurture During Middle Childhood, Blackwell Press, Oxford, UK, 1994.

Dickens, William and James R. Flynn, "Heritability Estimates versus Large Environmental Effects: The IQ Paradox Resolved, " forthcoming in Psychological Review.

Evans, William N., Wallace E. Oates, and Robert M. Schwab, "Measuring Peer Group Effects: A Study of Teenage Behavior," Journal of Political Economy, C (1992), 966-991.

Foster, Jennifer, "Peerless Perfomers: The Lack of Robust Peer Effects at a Large Public University," Ph.D. Dissertation, University of Maryland, 2002.

Freud, Sigmund, Civilization and Its Discontents, 1910.

Gaviria, Alejandro and Stephen Raphael, "School Based Peer Effects and Juvenile Behavior," Review of Economics and Statistics, v.83 (2001), 257-68.

Goldberger, Arthur S, "Economic and Mechanical Models of Intergenerational Transmission," American Economic Review, vol. 79, no. 3, June 1989, pp. 504-13

Grilliches, Z. and W. M. Mason, "Education, Income, and Ability, “ Journal of Political Economy, LXXX (1972), S74-S103. 
Hanushek, Eric, John F. Kain, Jacob M. Markman, and Steven G. Rivkin "Does Peer Ability Affect Student Achievement?”, Journal of Applied Econometrics 18(5), September/October 2003, pp. 527-544.

Harris, Judith Rich, The Nurture Assumption: Why Children Turn out the Way They Do, The Free Press, NY, 1998.

Herrnstein, Richard J. and Charles Murray, The Bell Curve: Intelligence and Class Structure in American Life, The Free Press, NY, 1994.

Hoxby, Caroline M., "The Effects of Class Size on Student Achievement: New

Evidence from Population Variation," Quarterly Journal of Economics, Vol. 115,

No. 4 (November 2000), 1239-1285.

Hume, David, Enquiry into the Human Understanding, 1748.

Jacob, Brian A, "Public Housing, Housing Vouchers, and Student Achievement: Evidence from Public Housing Demolitions in Chicago," American Economic Review, vol. 94, no. 1, March 2004, pp. 233-58.

Jencks, C., Inequality: A Reassessment of the Effects of Family and Schooling in America, Basic Books, NY, 1972.

Jencks, C. and M. Brown, "Genes and Social Stratification;” in P. Taubman (ed.), Kinometrics: The Determinants of Economic Success Within and Between Families, New York: North Holland Elsevier. In press.

Kain, John F., Eric A. Hanushek, Steven G. Rivkin, "Teachers, Schools, and Academic Achievement," National Bureau of Economic Research Working Paper No. 6691, Aug 1998 .

Katz, Lawrence F., Jeffrey R. Kling, and Jeffrey B. Liebman, "Moving to Opportunity in Boston: Early Results of a Randomized Mobility Experiment," Quarterly Journal of Economics, 116(2001), pp. 607-654.

Kling, Jeffrey R, Jens Ludwig and Lawrence F. Katz, "Youth Criminal Behavior in the Moving to Opportunity Experiment," Industrial Relations Section Working Paper \#482, Princeton University, March 2004.

Ludwig, Jens, Greg J. Duncan, and Paul Hirschfield, "Urban Poverty and Juvenile Crime: Evidence from a Randomized Housing Mobility Experiment," Quarterly Journal of Economics, 116(2001), pp. 655-680.

Loehlin, John C., Joseph M. Horn, and Lee Willerman, "Differential Inheritance of Mental Abilities in the Texas Adoption Project," Intelligence, XIX (1994), 325-336.

Loehlin, John C., Joseph M. Horn, and Lee Willerman, "Heredity, Environment, and Personality Change: Evidence from the Texas Adoption Project, "Journal of Personality, LVIII (1990), 221-243. 
Loehlin, John C., Joseph M. Horn, and Lee Willerman, "Personality Resemblances Between Unwed Mothers and Their Adopted-Away Offspring," Journal of Personality and Social Psychology, XLII (1982), 1089-1099.

Loehlin, John C., Lee Willerman, and Joseph M. Horn, "Personality Resemblance in Adoptive Families: A 10-Year Followup," Journal of Personality and Social Psychology, LIII (1987), 961-969.

Maughan, Barbara, Stephon Collishaw, and Andrew Pickles, "School Achievement and Adult Qualification Among Adoptees: A Longitudinal Study," Journal of Child Psychology and Psychiatry, XXXIX (1998), 669-685.

Mulligan, Casey B., Parental Priorities and Economic Inequality, Chicago: University of Chicago Press, 1997.

Nechyba, Thomas and Jacob Vigdor, "Peer Effects in North Carolina Public Schools," Mimeo, Duke University, 2003.

Plug, Erik, "Estimating the Effect of Mother's Schooling on Children's Schooling Using a Sample of Adoptees," American Economic Review, 94(1), pp. 358-368.

Plug, Erik and Wim Vijverberg, "Schooling, Family Background and Adoption: Is It Nature or Is It Nurture?," Journal of Political Economy, 111(3), pp. 611-641.

Ridley, Matt, Nature Via Nurture, New York: Harper Collins, 2003.

Rouse, Cecilia E., "Private School Vouchers and Student Achievement: An Evaluation of the Milwaukee Parental Choice Program," Quarterly Journal of Economics, vol. 113, no. 2, May 1998, pp. 553-602.

Scarr, Sandra and Richard Weinberg "The Influence of Family Background on Intellectual Attainment," American Sociological Review, XVIII (1978), 674-692.

Segal, Nancy L. and Thomas J. Bouchard, Entwined Lives: Twins and What They Tell Us About Human Behavior, E.P. Dutton, April, 1999.

Solon, Gary, "Intergenerational Income Mobility in the United States," American Economic Review, 82 (1992), 393-408.

Solon, Gary, "Intergenerational Mobility in the Labor Market," in Orley Ashenfelter and David Card eds., Handbook of Labor Economics, Vol 3. Elsevier Science B.V., 1999.

Taubman, Paul "Role of Parental Income in Educational Attainment," American Economic Review, LXXIX (1989), 57-61.

Vogler, G. P., T. I. A. Sorensen, A. J. Stunkard, M. R. Srinivasan, and D. C. Rao. 1995. "Influences of Genes and Shared Family Environment on Adult Body Mass Index Assessed in an Adoption Study by a Comprehensive Path Model." International Journal of Obesity 19:40-45.

Weinberg, Richard A., Sandra Scarr, and Irvin D. Waldman, "The Minnesota Transracial Adoption Study: A Follow-Up of IQ Test Performance at Adolescence," Intelligence, XVI (1992), 117-135. 
Wilson, R.S. and A. P. Matheny, Jr., "Behavior-Genetics Research in Infant Temperament: The Louisville Twin Study," in R. Plomin and J. Dunn (eds.) The Study of Temperament. (pp 81-97). Hillsdale, NJ: Lawrence Erlbaum.

Zimmerman, David J., "Regression Toward Mediocrity in Economic Stature," American Economic Review, 82(1992), 409-429. 


\section{Table 1}

Summary Statistics for Adoptees and

Biological Children in Same Families

\begin{tabular}{|c|c|c|c|c|c|c|c|}
\hline & & Adoptees & & Bio & logical & & \\
\hline Means for Children & Obs & Mean & $\begin{array}{l}\text { Std. } \\
\text { Dev. }\end{array}$ & Obs & Mean & $\begin{array}{l}\text { Std. } \\
\text { Dev. }\end{array}$ & $\begin{array}{l}\text { T Stat for } \\
\text { Difference }\end{array}$ \\
\hline Child is Male & 1567 & 0.30 & 0.46 & 1244 & 0.61 & 0.49 & 17.28 \\
\hline Child Age & 1562 & 27.82 & 4.74 & 1252 & 33.99 & 6.67 & 28.63 \\
\hline Child Age at Adoption & 1543 & 1.38 & 0.83 & & & & \\
\hline Child Adopted at Age 1+ & 1543 & 0.23 & 0.42 & & & & \\
\hline Child's Years Education & 1555 & 14.80 & 2.08 & 1235 & 15.66 & 2.37 & 10.20 \\
\hline Child has 4+ Years College & 1555 & 0.48 & 0.50 & 1235 & 0.65 & 0.48 & 9.22 \\
\hline SAT 25th Percentile Child's College & 730 & 1019.63 & 116.62 & 680 & 1033.11 & 121.64 & 2.12 \\
\hline SAT 75th Percentile Child's College & 733 & 1224.87 & 108.93 & 683 & 1240.05 & 112.98 & 2.57 \\
\hline Acceptance Rate of Child's College & 738 & 0.70 & 0.17 & 689 & 0.68 & 0.19 & -1.84 \\
\hline $\begin{array}{l}\text { Child's Graduated from a College w/ } \\
\text { US News Rank }\end{array}$ & 1555 & 0.35 & 0.48 & 1235 & 0.48 & 0.50 & 6.98 \\
\hline Child's Family Income & 1413 & 41.64 & 34.40 & 1176 & 61.08 & 42.71 & 12.83 \\
\hline Child Married? (0-1) & 1552 & 0.37 & 0.48 & 1229 & 0.65 & 0.48 & 15.16 \\
\hline Child's Number of Children & 1478 & 0.50 & 0.90 & 1194 & 1.22 & 1.31 & 16.92 \\
\hline Child Overweight $(0-1)$ & 1491 & 0.24 & 0.43 & 1201 & 0.34 & 0.47 & 5.67 \\
\hline Child Obese (0-1) & 1491 & 0.06 & 0.24 & 1201 & 0.07 & 0.25 & 1.07 \\
\hline Child Smokes & 1552 & 0.23 & 0.42 & 1223 & 0.12 & 0.32 & -7.64 \\
\hline Child Drinks & 1537 & 0.59 & 0.49 & 1207 & 0.66 & 0.47 & 3.92 \\
\hline Mother's Years Education & 1552 & 15.18 & 2.46 & 1247 & 15.07 & 2.45 & -1.17 \\
\hline Mother Has 4+ Years College & 1552 & 0.54 & 0.50 & 1247 & 0.51 & 0.50 & -1.42 \\
\hline Parent's Family Income At Adoption & 1530 & 32.52 & 23.96 & 1234 & 32.71 & 25.33 & .21 \\
\hline Parent's Family Income Now & 1538 & 77.99 & 44.16 & 1240 & 79.19 & 45.06 & .70 \\
\hline Mother Is Overweight & 1485 & 0.47 & 0.50 & 1196 & 0.42 & 0.49 & -2.26 \\
\hline Mother Smokes & 1540 & 0.03 & 0.17 & 1234 & 0.02 & 0.14 & -1.50 \\
\hline Mother Drinks & 1537 & 0.52 & 0.50 & 1233 & 0.53 & 0.50 & .62 \\
\hline Age Gap: Mother - Child & 1556 & 31.47 & 5.47 & 1244 & 27.00 & 5.64 & -21.20 \\
\hline
\end{tabular}




\section{Table 2 \\ Frequency and Composition of Family Sizes \\ In the Sample}

Families have at least one Holt adoptee from Korea in order to be included in the sample. Family size and gender is as reported by parents. We have outcomes data on up to 5 children in each family.

\begin{tabular}{rrrr}
\hline \hline $\begin{array}{r}\text { Total } \\
\text { Number of } \\
\text { Children in } \\
\text { Family }\end{array}$ & $\begin{array}{r}\text { Number } \\
\text { of } \\
\text { Families }\end{array}$ & $\begin{array}{r}\text { Fraction } \\
\text { Adoptees }\end{array}$ & $\begin{array}{r}\text { Fraction } \\
\text { Girls }\end{array}$ \\
& & & \\
1 & 60 & 1.000 & 0.783 \\
2 & 323 & 0.799 & 0.627 \\
3 & 298 & 0.595 & 0.555 \\
4 & 214 & 0.550 & 0.530 \\
5 & 106 & 0.546 & 0.546 \\
6 & 44 & 0.552 & 0.536 \\
7 & 41 & 0.643 & 0.543 \\
\hline \hline
\end{tabular}




\section{Table 3 \\ Size of Nurture Effect Relative to Total Effect Using Transmission Coefficients From Parents To Children I.e. Coefficient on Parent's Outcome When Child's Outcome is Dependent Variable}

Each coefficient is from a separate univariate regression of child's outcome on mother's outcome. I show separate coefficients for the adoptees and the biological children in the same families. I obtain very similar results when I include dummies for child age and gender and when I control for parental income and education (see next two tables for these results).

\begin{tabular}{|c|c|c|c|c|}
\hline & $\begin{array}{r}\text { Adoptee's } \\
\text { Outcome } \\
\text { Regressed on } \\
\text { Mother's Outcome }\end{array}$ & $\begin{array}{r}\text { Biological } \\
\text { Child's } \\
\text { Outcome } \\
\text { Regressed } \\
\text { on Mother's }\end{array}$ & $\begin{array}{r}\text { Ratio of } \\
\text { Adoptee } \\
\text { Transmission to } \\
\text { Biological }\end{array}$ & $\begin{array}{r}\text { T-stat for } \\
\text { Difference } \\
\text { in } \\
\text { Coefficients }\end{array}$ \\
\hline \multirow[t]{2}{*}{ Years of Education } & 0.069 & 0.299 & 0.231 & 6.176 \\
\hline & $(0.022)^{* *}$ & $(0.032)^{* *}$ & & \\
\hline \multirow[t]{2}{*}{ Log Household Income } & -0.087 & 0.161 & -0.540 & 4.411 \\
\hline & $(0.037)^{*}$ & $(0.051)^{* *}$ & & \\
\hline Has 4+ Years College & $\begin{array}{r}0.069 \\
(0.027)^{* *}\end{array}$ & $\begin{array}{r}0.257 \\
(0.031)^{* *}\end{array}$ & 0.268 & 4.805 \\
\hline Height Inches & $\begin{array}{r}0.036 \\
(0.040)\end{array}$ & $\begin{array}{r}0.456 \\
(0.057)^{* *}\end{array}$ & 0.079 & 5.616 \\
\hline Obese & $\begin{array}{r}0.031 \\
(0.018)\end{array}$ & $\begin{array}{r}0.103 \\
(0.029)^{* *}\end{array}$ & 0.301 & 2.107 \\
\hline Overweight & $\begin{array}{r}0.006 \\
(0.023)\end{array}$ & $\begin{array}{r}0.188 \\
(0.031)^{* *}\end{array}$ & 0.032 & 4.809 \\
\hline BMI & $\begin{array}{r}0.021 \\
(0.021)\end{array}$ & $\begin{array}{r}0.235 \\
(0.035)^{* *}\end{array}$ & 0.089 & 5.394 \\
\hline Smokes & $\begin{array}{r}0.093 \\
(0.071)\end{array}$ & $\begin{array}{r}0.112 \\
(0.096)\end{array}$ & 0.830 & 0.202 \\
\hline Drinks $(0-1)$ & $\begin{array}{r}0.206 \\
(0.028)^{* *}\end{array}$ & $\begin{array}{r}0.302 \\
(0.033)^{* *}\end{array}$ & 0.682 & 2.511 \\
\hline Observations & 1539 & 1220 & & \\
\hline
\end{tabular}




\section{Table 3A \\ Transmission in Holt Sample Versus Transmission in Other Samples}

Below I report transmission coefficients for education and income in the Holt Sample, my calculations from the NLSY79, Björklund et al's [2004] coefficients for Sweden, Solon[1999] and Zimmerman [1992] for PSID income, Plug [2004] for the Wisconsin Longitudinal Survey (WLS).

\begin{tabular}{|c|c|c|c|c|}
\hline & $\begin{array}{r}\text { Transmission of } \\
\text { Years of } \\
\text { Education (Mother- } \\
\text { Child) }\end{array}$ & $\begin{array}{r}\text { Transmission } \\
\text { of 4+ Years } \\
\text { College } \\
\text { (Mother-Child) }\end{array}$ & $\begin{array}{r}\text { Transmission of } \\
\text { Income }\end{array}$ & $\mathrm{N}$ \\
\hline Holt Biological & $\begin{array}{r}0.299 \\
(0.032)^{* *}\end{array}$ & $\begin{array}{r}0.257 \\
(0.031)^{* *}\end{array}$ & $\begin{array}{r}0.161 \\
(0.051)^{* *}\end{array}$ & 1,213 \\
\hline Swedish Biological & $\begin{array}{r}.241 \\
(.001)^{* *}\end{array}$ & $\begin{array}{r}.268 \\
(.004)^{* *}\end{array}$ & $\begin{array}{r}.264 \\
(.004)^{* *}\end{array}$ & 148,496 \\
\hline PSID single year Biological & & & $.25-.30$ & 300 \\
\hline NLSY Biological & $\begin{array}{r}.401 \\
(.011)^{* *}\end{array}$ & $\begin{array}{r}.440 \\
(.018)^{* *}\end{array}$ & $\begin{array}{r}.290 \\
(.025)^{* *}\end{array}$ & 5,614 \\
\hline Holt Adoptees & $\begin{array}{r}0.069 \\
(0.021)^{* *}\end{array}$ & $\begin{array}{r}0.069 \\
(0.027)^{* *}\end{array}$ & $\begin{array}{r}-0.087 \\
(0.037)^{*}\end{array}$ & 1,642 \\
\hline Swedish Adoptees & $\begin{array}{r}.114 \\
(.007)^{* *}\end{array}$ & $\begin{array}{r}.107 \\
(.013)^{* *}\end{array}$ & $\begin{array}{r}.154 \\
(.021)^{* *}\end{array}$ & 7,498 \\
\hline NLSY Adoptees & $\begin{array}{r}.277 \\
(.060)^{* *}\end{array}$ & $\begin{array}{r}.420 \\
(.078)^{* *}\end{array}$ & $\begin{array}{r}.112 \\
(.117)\end{array}$ & 170 \\
\hline WLS Adoptees & $\begin{array}{r}.276 \\
(.063)^{* *}\end{array}$ & $\begin{array}{r}.178 \\
(.063)^{* *}\end{array}$ & & 610 \\
\hline
\end{tabular}




\section{Table 3B \\ Sibling "Transmission" Coefficients}

Below I report coefficients from regressing child outcomes on older sibling's outcome. In column (2) I form all unique pairs of biological siblings and regress the younger sibling's outcome on the older sibling's. I include dummies for age and gender of each sibling in the pair. In column (1) I use all possible pairs of adoptive (non-biologically related) siblings. These latter pairs can be formed from two adoptees in the family or from one adoptee and one non-adoptee.

\begin{tabular}{|c|c|c|c|}
\hline & $\begin{array}{r}(1) \\
\text { Child } \\
\text { Outcome } \\
\text { Regressed on } \\
\text { Adoptive } \\
\text { Sibling's }\end{array}$ & $\begin{array}{r}(2) \\
\text { Child } \\
\text { Outcome } \\
\text { Regressed on } \\
\text { Biological } \\
\text { Sibling's }\end{array}$ & $\begin{array}{r}\text { (3) } \\
\text { Ratio of } \\
\text { adoptive to } \\
\text { biological }\end{array}$ \\
\hline Years of Education & $\begin{array}{r}0.088 \\
(0.024)^{* *}\end{array}$ & $\begin{array}{r}0.290 \\
(0.033)^{* *}\end{array}$ & .30 \\
\hline Has 4+ Years College & $\begin{array}{r}0.098 \\
(0.028)^{* *}\end{array}$ & $\begin{array}{r}0.243 \\
(0.035)^{* *}\end{array}$ & .40 \\
\hline Log Household Income & $\begin{array}{r}0.158 \\
(0.029)^{* *}\end{array}$ & $\begin{array}{r}0.288 \\
(0.039)^{* *}\end{array}$ & .55 \\
\hline Drinks (yes/no) & $\begin{array}{r}0.323 \\
(0.030)^{* *}\end{array}$ & $\begin{array}{r}0.359 \\
(0.039)^{* *}\end{array}$ & .90 \\
\hline $\begin{array}{l}\text { BMI } \\
\text { Observations } \\
\text { R-squared }\end{array}$ & $\begin{array}{r}0.042 \\
(0.027) \\
1764 \\
0.092\end{array}$ & $\begin{array}{r}0.210 \\
(0.033) * * \\
1132 \\
0.169\end{array}$ & .20 \\
\hline
\end{tabular}

Robust standard errors in parentheses

* significant at 5\%;** significant at $1 \%$ 


\section{Table 4}

\section{Effects of Family Environment on Educational Outcomes and Income}

Each column is a separate regression. I pool data for adoptees and biological children. Adoptees are always the base category. Slopes for the biological children are obtained by adding the interaction term (e.g. bio*mother's education) to the relevant adoptee coefficient (e.g. mother's education). Dependent variables are years of education, a dummy for having 4 or more years of college, the $75^{\text {th }}$ percentiles of the SAT distribution and the log of child's family income. Regressions include (but suppress) age dummies and a separate intercept for biological children.

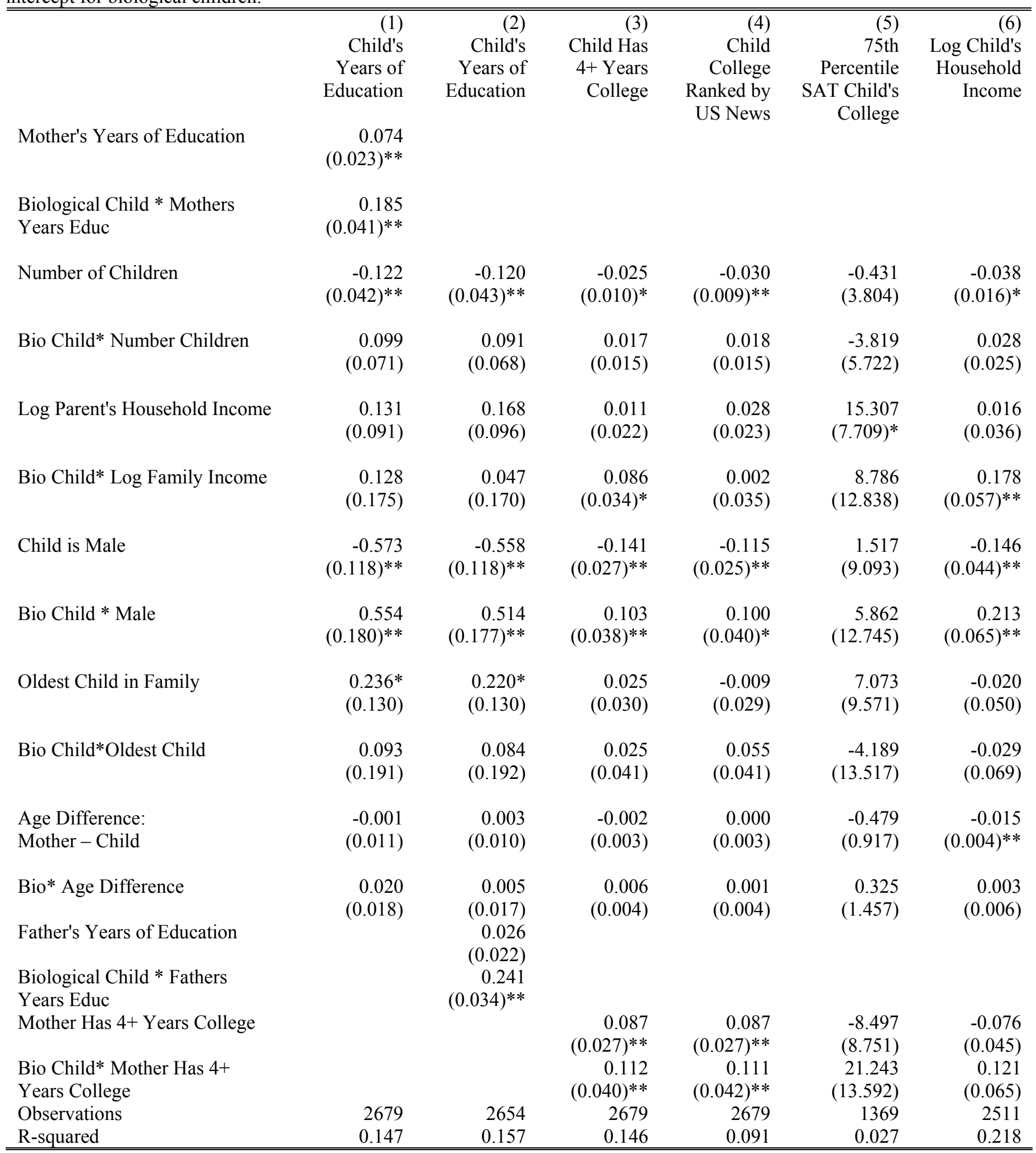




\section{Table 5}

\section{Effects of Family Environment on Health Outcomes}

Each column is a separate regression. I pool data for adoptees and biological children. Adoptees are always the base category. Slopes for the biological children are obtained by adding the interaction term (e.g. bio*mother's education) to the relevant adoptee coefficient (e.g. mother's education). Dependent variables are child's BMI and dummies for drinking, smoking, obese and overweight. BMI is defined from self reported weight and height. Overweight is defined as a BMI $>=25$ and obese is having a BMI $>=30$. Regressions include (but suppress) age dummies, a separate intercept for biological children, dummies for being the oldest child, and controls for the age difference between the mother and child.

\begin{tabular}{|c|c|c|c|c|c|}
\hline Mother Drinks & $\begin{array}{r}(1) \\
\text { Child Drinks } \\
(\text { yes/no) } \\
0.185 \\
(0.029)^{* *}\end{array}$ & $\begin{array}{r}(2) \\
\text { Child Smokes } \\
(\text { yes/no) }\end{array}$ & $\begin{array}{r}(3) \\
\text { Child's BMI }\end{array}$ & $\begin{array}{r}(4) \\
\text { Child } \\
\text { Overweight }\end{array}$ & $\begin{array}{r}(5) \\
\text { Child Obese }\end{array}$ \\
\hline Bio Child* Mother drinks & $\begin{array}{r}0.076 \\
(0.041)\end{array}$ & & & & \\
\hline Mother Smokes & & $\begin{array}{r}0.108 \\
(0.072)\end{array}$ & & & \\
\hline Bio Child* Mother smokes & & $\begin{array}{r}-0.009 \\
(0.102)\end{array}$ & & & \\
\hline Mother's BMI & & & $\begin{array}{r}0.013 \\
(0.020)\end{array}$ & & \\
\hline Bio Child* Mother's BMI & & & $\begin{array}{r}0.222 \\
(0.041)^{* *}\end{array}$ & & \\
\hline Mother Overweight & & & & $\begin{array}{r}0.002 \\
(0.023)\end{array}$ & \\
\hline Bio Child* Mother Overweight & & & & $\begin{array}{r}0.189 \\
(0.037)^{* *}\end{array}$ & \\
\hline Mother Obese & & & & & $\begin{array}{r}0.025 \\
(0.019)\end{array}$ \\
\hline Bio Child* Mother Obese & & & & & $\begin{array}{r}0.080 \\
(0.035)^{*}\end{array}$ \\
\hline Mother's Years of Education & $\begin{array}{r}0.011 \\
(0.006)\end{array}$ & $\begin{array}{r}0.001 \\
(0.005)\end{array}$ & $\begin{array}{r}-0.078 \\
(0.047)\end{array}$ & $\begin{array}{r}-0.013 \\
(0.005)^{* *}\end{array}$ & $\begin{array}{r}-0.004 \\
(0.003)\end{array}$ \\
\hline Biological Child * Mothers Years Educ & $\begin{array}{r}-0.002 \\
(0.009)\end{array}$ & $\begin{array}{r}-0.011 \\
(0.007)\end{array}$ & $\begin{array}{r}0.039 \\
(0.076)\end{array}$ & $\begin{array}{r}0.004 \\
(0.009)\end{array}$ & $\begin{array}{r}0.000 \\
(0.005)\end{array}$ \\
\hline Number of Children & $\begin{array}{r}-0.006 \\
(0.010)\end{array}$ & $\begin{array}{r}0.011 \\
(0.009)\end{array}$ & $\begin{array}{r}0.089 \\
(0.075)\end{array}$ & $\begin{array}{r}0.013 \\
(0.008)\end{array}$ & $\begin{array}{r}0.003 \\
(0.005)\end{array}$ \\
\hline Bio Child* Number Children & $\begin{array}{r}0.005 \\
(0.015)\end{array}$ & $\begin{array}{r}-0.014 \\
(0.011)\end{array}$ & $\begin{array}{r}0.005 \\
(0.132)\end{array}$ & $\begin{array}{r}0.004 \\
(0.015)\end{array}$ & $\begin{array}{r}0.003 \\
(0.009)\end{array}$ \\
\hline Log Parent's Household Income & $\begin{array}{r}0.016 \\
(0.026)\end{array}$ & $\begin{array}{r}0.007 \\
(0.021)\end{array}$ & $\begin{array}{r}-0.146 \\
(0.188)\end{array}$ & $\begin{array}{r}0.009 \\
(0.021)\end{array}$ & $\begin{array}{r}-0.001 \\
(0.013)\end{array}$ \\
\hline Bio Child* Log Family Income & $\begin{array}{r}0.029 \\
(0.037)\end{array}$ & $\begin{array}{r}0.007 \\
(0.027)\end{array}$ & $\begin{array}{r}-0.038 \\
(0.302)\end{array}$ & $\begin{array}{r}0.019 \\
(0.035)\end{array}$ & $\begin{array}{r}-0.021 \\
(0.018)\end{array}$ \\
\hline Child is Male & $\begin{array}{r}0.058 \\
(0.028)^{*}\end{array}$ & $\begin{array}{r}0.124 \\
(0.026)^{* *}\end{array}$ & $\begin{array}{r}1.652 \\
(0.223)^{* *}\end{array}$ & $\begin{array}{r}0.196 \\
(0.027)^{* *}\end{array}$ & $\begin{array}{r}0.036 \\
(0.015)^{*}\end{array}$ \\
\hline Bio Child * Male & $\begin{array}{r}0.056 \\
(0.042)\end{array}$ & $\begin{array}{r}-0.052 \\
(0.032)\end{array}$ & $\begin{array}{r}-0.047 \\
(0.352)\end{array}$ & $\begin{array}{r}0.009 \\
(0.039)\end{array}$ & $\begin{array}{r}-0.044 \\
(0.022)^{*}\end{array}$ \\
\hline Observations & 2609 & 2640 & 2500 & 2500 & 2500 \\
\hline R-squared & 0.106 & 0.044 & 0.111 & 0.091 & 0.024 \\
\hline
\end{tabular}

Robust standard errors in parentheses

$*$ significant at $5 \%$; ** significant at $1 \%$ 


\section{Table 6 \\ Effects of Family Structure (Number of Adoptees Versus Non-Adoptees) \\ On Outcomes}

Each column is a separate regression. Regressions include (but suppress) age dummies, a separate intercept for biological children, a set of dummies for family size, dummies for being the oldest child, controls for the age difference between the mother and child, controls for mothers education and family income. The right hand side variables of interest are the following three mutually exclusive and exhaustive categories: 1) being the only adoptee in the family, 2) being an adoptee in a family with $2+$ adoptees and biological children, or 3) being an adoptee in a family with $2+$ adoptees and no biological children.

\begin{tabular}{|c|c|c|c|c|}
\hline & (1) & (2) & (3) & (4) \\
\hline & $\begin{array}{r}\text { Child Four Year } \\
\text { College Ranked } \\
\text { by US News }\end{array}$ & $\begin{array}{r}\text { Child's Years of } \\
\text { Education }\end{array}$ & Child's BMI & $\begin{array}{r}\text { Child Drinks } \\
\text { (yes/no) }\end{array}$ \\
\hline $\begin{array}{l}\text { Child is Only Adoptee in } \\
\text { Family }\end{array}$ & $\begin{array}{r}0.047 \\
(0.075)\end{array}$ & $\begin{array}{r}-0.373 \\
(0.242)\end{array}$ & $\begin{array}{r}0.813 \\
(0.417)\end{array}$ & $\begin{array}{l}-0.063 \\
(0.053)\end{array}$ \\
\hline $\begin{array}{l}\text { Family Has } 2+\text { Adoptees } \\
\text { and Biological }\end{array}$ & $\begin{array}{r}0.012 \\
(0.079)\end{array}$ & $\begin{array}{r}-0.296 \\
(0.267)\end{array}$ & $\begin{array}{r}0.838 \\
(0.461)\end{array}$ & $\begin{array}{r}-0.138 \\
(0.064)^{*}\end{array}$ \\
\hline $\begin{array}{l}\text { Family Has } 2+\text { Adoptees } \\
\text { and No Biological }\end{array}$ & $\begin{array}{r}0.025 \\
(0.076)\end{array}$ & $\begin{array}{r}-0.353 \\
(0.241)\end{array}$ & $\begin{array}{r}0.787 \\
(0.419)\end{array}$ & $\begin{array}{r}-0.117 \\
(0.057)^{*}\end{array}$ \\
\hline $\begin{array}{l}\text { Observations } \\
\text { R-squared }\end{array}$ & $\begin{array}{r}2748 \\
0.068\end{array}$ & $\begin{array}{r}2762 \\
0.098\end{array}$ & $\begin{array}{r}2673 \\
0.069\end{array}$ & $\begin{array}{r}2724 \\
0.047\end{array}$ \\
\hline
\end{tabular}

Robust standard errors in parentheses

$*$ significant at 5\%;** significant at $1 \%$ 


\section{Appendix Table 1: Is Response Pattern Correlated with Family or Child Characteristics?}

This is an OLS regression of the dummy for response on a series of background variables for the parents and the adoptee. All the right hand side variables are pulled from Holt Records. We use data for 216 non-responders and 674 responders. We drew a random sample of 500 non-responders. We include all observations for which we have the data from Holt records.

\begin{tabular}{lr}
\hline \hline & Responded to Survey \\
Log (Family Income) & 0.003 \\
Mother's Years of Education & $(0.027)$ \\
& 0.007 \\
Father's Years of Education & $(0.008)$ \\
& 0.008 \\
Weight At Admission to Holt & $(0.006)$ \\
& 0.000 \\
Height At Admission to Holt & $(0.003)$ \\
& -0.004 \\
Age at Arrival in US & $(0.004)$ \\
& 0.011 \\
Constant & $(0.008)$ \\
Observations & 0.599 \\
R-squared & $(0.257)^{*}$ \\
\hline \hline
\end{tabular}

Standard errors in parentheses

$*$ significant at $5 \% ; * *$ significant at $1 \%$ 


\section{Appendix 2 \\ Child's Pre-Treatment Characteristics \\ Vs. Parent's Pre-Treatment Characteristics}

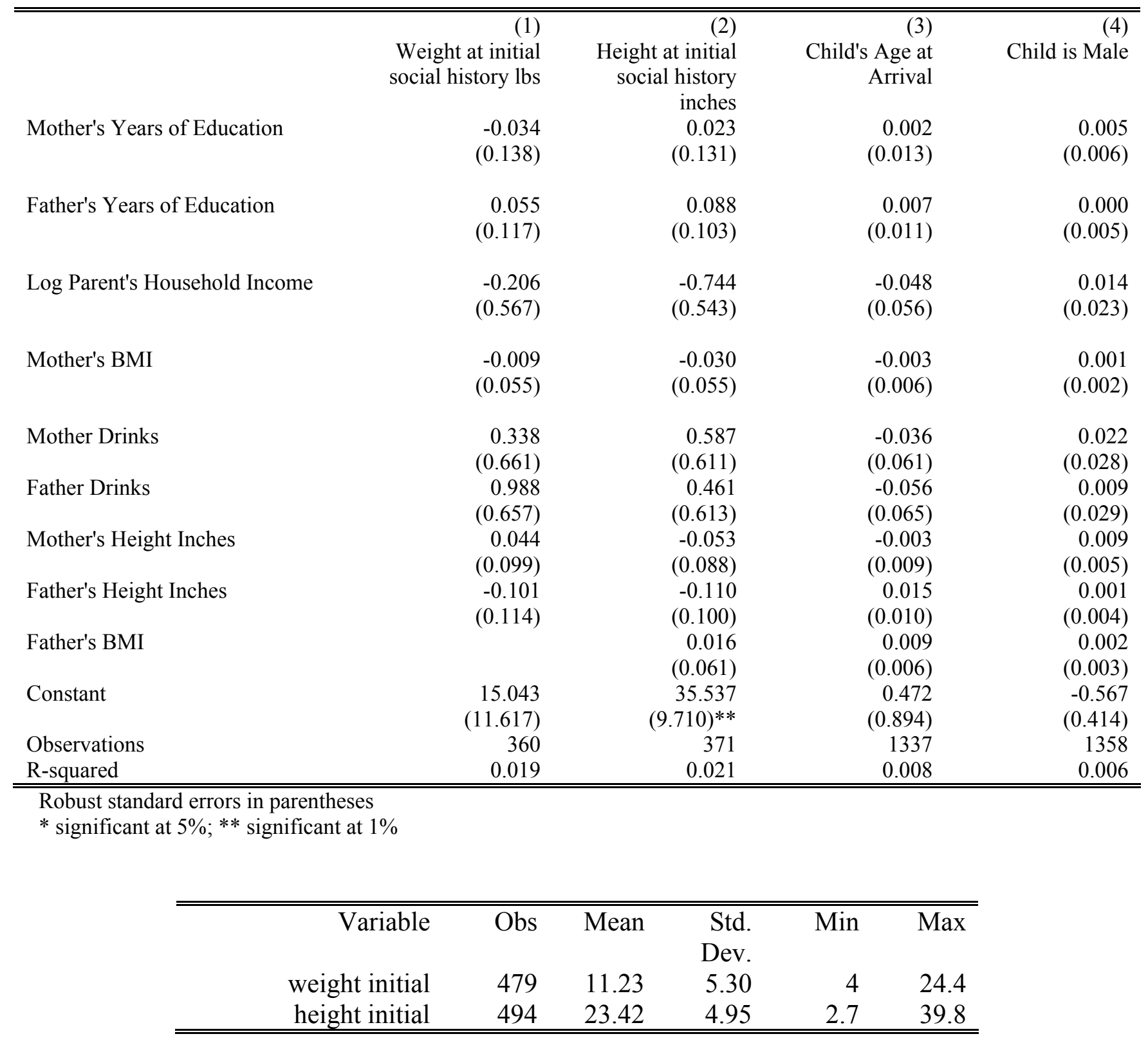




\section{Appendix 3 \\ Variance Explained By Nurture Effects And Total Variance Explained}

Each R-squared is from a separate regression of child's outcome on mother's and father's education, college status, smoking and drinking status, number of children, family income, height, weight, obesity and overweight status

\begin{tabular}{lrrr}
\hline \hline Child's Outcome & $\begin{array}{r}\text { R-squared } \\
\text { Adoptees }\end{array}$ & $\begin{array}{r}\text { R-squared } \\
\text { Biological } \\
\text { Children }\end{array}$ & $\begin{array}{r}\text { Ratio } \\
\text { (adoptees/ } \\
\text { biological) }\end{array}$ \\
Years of Education & 0.053 & 0.187 & 0.281 \\
Has 4+ Years of College & 0.060 & 0.181 & 0.332 \\
Graduated from A US News Ranked & 0.073 & 0.132 & 0.550 \\
College & & & \\
SAT 75th Percentile of College 2003 & 0.025 & 0.078 & 0.320 \\
Acceptance Rate of College 2003 & 0.038 & 0.058 & 0.656 \\
Log (Income) & 0.113 & 0.056 & 2.014 \\
Family Income & 0.069 & 0.058 & 1.191 \\
Drinks? (0-1) & 0.079 & 0.174 & 0.454 \\
Smokes? (0-1) & 0.024 & 0.035 & 0.690 \\
Has Asthma & 0.012 & 0.020 & 0.603 \\
BMI & 0.012 & 0.128 & 0.096 \\
Overweight? (0-1) & 0.014 & 0.065 & 0.219 \\
Height in Inches & 0.016 & 0.169 & 0.094 \\
Married? & 0.068 & 0.041 & 1.671 \\
Number of Children & 0.078 & 0.138 & 0.564 \\
\hline \hline
\end{tabular}




\section{Appendix 4 \\ Marital Status, Number Kids Outcomes}

Each column is a separate regression. Regressions include (but suppress) age dummies and a separate intercept for biological children. I pool the adoptees and the biological children. Adoptees are the base category and the total slope for the biological children is obtained by adding the base (adoptee) coefficient to the relevant interaction term.

\begin{tabular}{lrrr}
\hline \hline & $(1)$ & $(2)$ & $(3)$ \\
& Child is & Number of & Has Children \\
Mother's Years of Education & -0.005 & -0.022 & -0.011 \\
& $(0.005)$ & $(0.010)^{*}$ & $(0.005)^{*}$ \\
Biological Child * Mothers Years & -0.001 & -0.021 & -0.007 \\
Educ & $(0.008)$ & $(0.020)$ & $(0.008)$ \\
Number of Children & & & \\
& 0.011 & 0.032 & 0.020 \\
Bio Child* Number Children & $(0.008)$ & $(0.016)^{*}$ & $(0.008)^{* *}$ \\
& -0.005 & 0.070 & 0.007 \\
& $(0.013)$ & $(0.037)$ & $(0.014)$ \\
Log Parent's Household Income & & & -0.007 \\
& -0.023 & -0.044 & $(0.020)$ \\
Bio Child* Log Family Income & $(0.020)$ & $(0.042)$ & -0.023 \\
& 0.012 & -0.077 & $(0.031)$ \\
Child is Male & $(0.032)$ & $(0.089)$ & -0.095 \\
Bio Child * Male & & & $(0.023)^{* *}$ \\
& -0.109 & -0.176 & 0.036 \\
Observations & $(0.024)^{* *}$ & $(0.042)^{* *}$ & $(0.036)$ \\
R-squared & 0.064 & -0.034 & 2674 \\
\hline \hline
\end{tabular}

Robust standard errors in parentheses

$*$ significant at 5\%; ** significant at $1 \%$ 


\section{Appendix 5}

\section{Do Effects Differ by Adoptee's Gender?}

Sample is limited to adoptees. Each column is a separate regression. Girls are the base category and I interact the dummy for boys with all the right hand side variables of interest. Age dummies are included but not reported.



Robust standard errors in parentheses

* significant at $5 \% ; * *$ significant at $1 \%$ 


\section{Appendix 6}

\section{Does the Gender Mix Matter for Adoptees?}

Sample is limited to adoptees. Each column is a separate regression. Column (1) is just for girls and column (2) is just for boys. Age dummies are included but coefficients are not reported.



Robust standard errors in parentheses

$*$ significant at $5 \% ; * *$ significant at $1 \%$ 


\section{Appendix 7 \\ Does Age at Adoption Affect Outcomes?}

Here we compare the adoptees who are adopted at age $<1$ year to all other adoptees in the sample who are adopted at age 1-5. Many other specifications of age at adoption were tried and all were equally unenlightening (i.e. yielded large standard errors).

\begin{tabular}{|c|c|c|c|c|c|c|}
\hline & (1) & (2) & (3) & (4) & (5) & (6) \\
\hline & $\begin{array}{l}\text { Child's Years } \\
\text { of Education }\end{array}$ & $\begin{array}{r}\text { Child Four } \\
\text { Year College } \\
\text { Ranked by } \\
\text { US News }\end{array}$ & $\begin{array}{r}\text { Log Child's } \\
\text { Household } \\
\text { Income }\end{array}$ & $\begin{array}{r}\text { Child Drinks } \\
\text { (yes/no) }\end{array}$ & $\begin{array}{r}\text { Child } \\
\text { Smokes } \\
\text { (yes/no) }\end{array}$ & Child's BMI \\
\hline Adopted Age 1+ (ie 1-5) & $\begin{array}{r}0.412 \\
(1.009)\end{array}$ & $\begin{array}{r}0.085 \\
(0.193)\end{array}$ & $\begin{array}{r}0.093 \\
(0.392)\end{array}$ & $\begin{array}{r}-0.437 \\
(0.242)\end{array}$ & $\begin{array}{r}-0.300 \\
(0.200)\end{array}$ & $\begin{array}{r}0.780 \\
(2.101)\end{array}$ \\
\hline Mother's Years of Education & $\begin{array}{r}0.078 \\
(0.027)^{* *}\end{array}$ & & & $\begin{array}{r}0.011 \\
(0.007)\end{array}$ & $\begin{array}{r}-0.002 \\
(0.006)\end{array}$ & $\begin{array}{r}-0.080 \\
(0.055)\end{array}$ \\
\hline Adopted Age $1+*$ Mother's & -0.070 & & & -0.002 & 0.019 & 0.061 \\
\hline Years Education & $(0.051)$ & & & $(0.012)$ & $(0.011)$ & $(0.088)$ \\
\hline Number of Children & $\begin{array}{r}-0.090 \\
(0.046)^{*}\end{array}$ & $\begin{array}{r}-0.026 \\
(0.011)^{*}\end{array}$ & $\begin{array}{r}-0.003 \\
(0.021)\end{array}$ & $\begin{array}{r}-0.010 \\
(0.011)\end{array}$ & $\begin{array}{r}0.005 \\
(0.009)\end{array}$ & $\begin{array}{r}0.141 \\
(0.084)\end{array}$ \\
\hline $\begin{array}{l}\text { Adopted Age } 1+* \text { Number of } \\
\text { Children }\end{array}$ & $\begin{array}{r}-0.112 \\
(0.080)\end{array}$ & $\begin{array}{r}-0.026 \\
(0.017)\end{array}$ & $\begin{array}{r}-0.054 \\
(0.032)\end{array}$ & $\begin{array}{r}-0.024 \\
(0.018)\end{array}$ & $\begin{array}{r}-0.013 \\
(0.015)\end{array}$ & $\begin{array}{r}-0.306 \\
(0.130)^{*}\end{array}$ \\
\hline Log Parent's Household Income & $\begin{array}{r}0.010 \\
(0.103)\end{array}$ & $\begin{array}{r}0.040 \\
(0.027)\end{array}$ & $\begin{array}{r}-0.059 \\
(0.044)\end{array}$ & $\begin{array}{r}0.004 \\
(0.029)\end{array}$ & $\begin{array}{r}0.004 \\
(0.023)\end{array}$ & $\begin{array}{l}-0.117 \\
(0.206)\end{array}$ \\
\hline $\begin{array}{l}\text { Adopted Age } 1+* \text { Log Family } \\
\text { Income }\end{array}$ & 0.153 & -0.018 & 0.022 & 0.125 & 0.027 & -0.188 \\
\hline Mother Has 4+ Years College & $(0.192)$ & $\begin{array}{r}(0.045) \\
0.123 \\
(0.034)^{* *}\end{array}$ & $\begin{array}{l}(0.092) \\
-0.072 \\
(0.056)\end{array}$ & $(0.048)^{* *}$ & $(0.043)$ & $(0.366)$ \\
\hline $\begin{array}{l}\text { Adopted Age } 1+* \text { Mother Has } \\
4+\text { Years College }\end{array}$ & & $\begin{array}{l}-0.032 \\
(0.059)\end{array}$ & $\begin{array}{l}-0.102 \\
(0.106)\end{array}$ & & & \\
\hline Mother's Drinks Per Day & & & & $\begin{array}{r}0.100 \\
(0.039)^{* *}\end{array}$ & & \\
\hline Mother's BMI & & & & & & $\begin{array}{r}0.005 \\
(0.025)\end{array}$ \\
\hline Adopted Age $1+*$ Mother's BMI & & & & & & $\begin{array}{r}-0.008 \\
(0.039)\end{array}$ \\
\hline Constant & $\begin{array}{r}13.984 \\
(0.511)^{* *}\end{array}$ & $\begin{array}{r}0.288 \\
(0.120)^{*}\end{array}$ & $\begin{array}{r}3.721 \\
(0.191)^{* *}\end{array}$ & $\begin{array}{r}0.406 \\
(0.133)^{* *}\end{array}$ & $\begin{array}{r}0.222 \\
(0.113)^{*}\end{array}$ & $\begin{array}{r}24.213 \\
(1.311)^{* *}\end{array}$ \\
\hline Mother Smokes & & & & & $\begin{array}{r}0.104 \\
(0.069)\end{array}$ & \\
\hline $\begin{array}{l}\text { Adopted Age } 1+* \text { Mother } \\
\text { Smokes }\end{array}$ & & & & & $\begin{array}{l}-0.092 \\
(0.128)\end{array}$ & \\
\hline $\begin{array}{l}\text { Adopted Age } 1+* \text { Mother's } \\
\text { Drinks Per Day }\end{array}$ & & & & $\begin{array}{r}0.076 \\
(0.075)\end{array}$ & & \\
\hline $\begin{array}{l}\text { Observations } \\
\text { R-squared }\end{array}$ & $\begin{array}{r}1587 \\
0.031 \\
\end{array}$ & $\begin{array}{r}1391 \\
0.049 \\
\end{array}$ & $\begin{array}{r}1461 \\
0.013 \\
\end{array}$ & $\begin{array}{r}1555 \\
0.037 \\
\end{array}$ & $\begin{array}{r}1570 \\
0.009 \\
\end{array}$ & $\begin{array}{r}1474 \\
0.010 \\
\end{array}$ \\
\hline
\end{tabular}

Robust standard errors in parentheses

* significant at $5 \% ; * *$ significant at $1 \%$ 


\section{Figure 1: Mean (College Attendance) By Family Size}

non-adoptees (higher line) shown in red, adoptees shown in blue

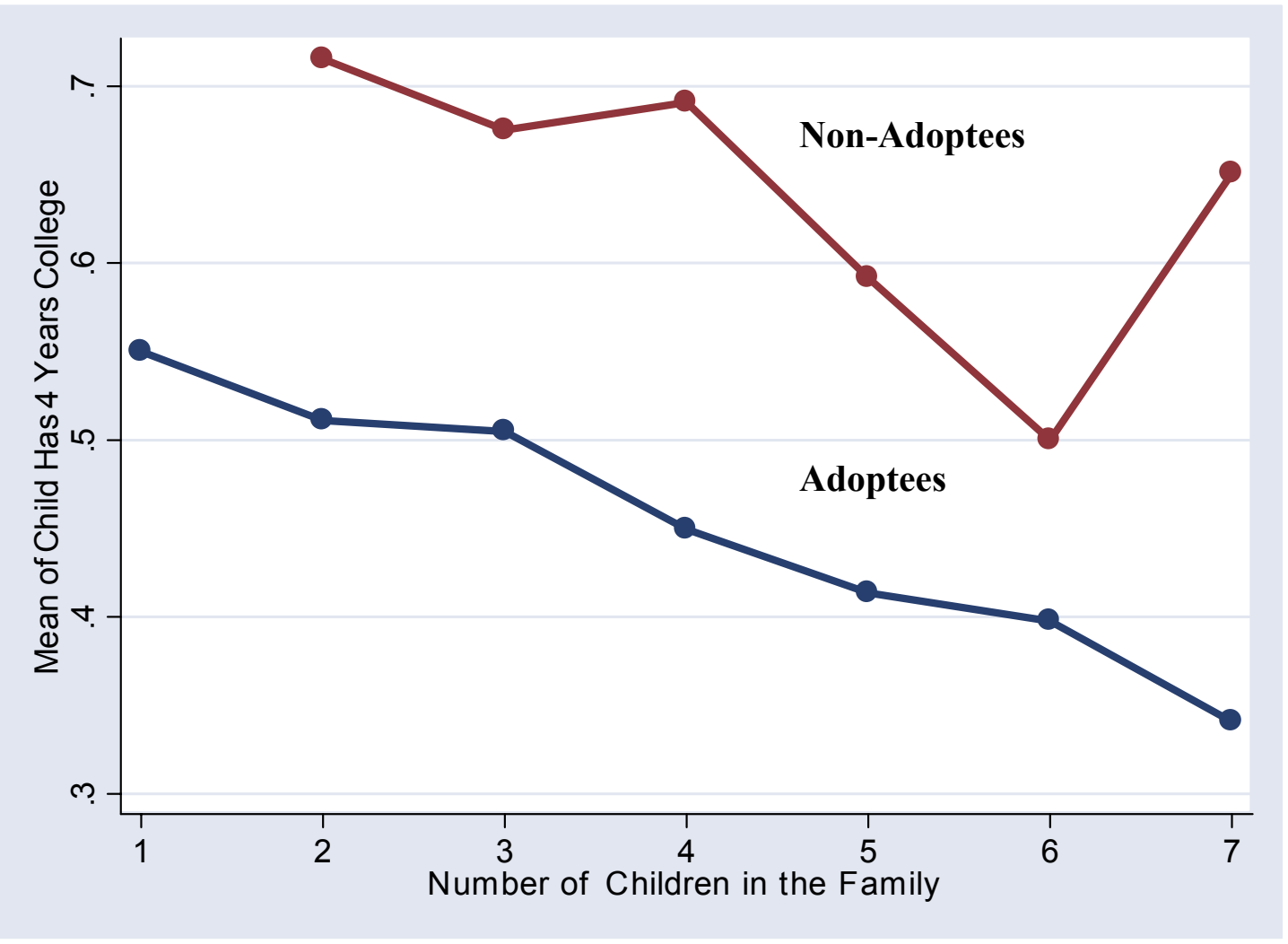

Sample Sizes in Above Graph

\begin{tabular}{lrrr}
\hline \hline Children & $\begin{array}{r}\text { Non- } \\
\text { Adoptees }\end{array}$ & Adoptees & $\begin{array}{r}\text { P Value for } \\
\text { Diff In Mean } \\
\text { Outcomes }\end{array}$ \\
1 & & 60 & \\
2 & 123 & 450 & 0.00 \\
3 & 348 & 400 & 0.00 \\
4 & 370 & 322 & 0.00 \\
5 & 231 & 167 & 0.00 \\
6 & 94 & 78 & 0.33 \\
7 & 69 & 78 & 0.00 \\
\hline \hline
\end{tabular}




\section{Figure 2: Mean Child's Years of Education Vs Mothers}

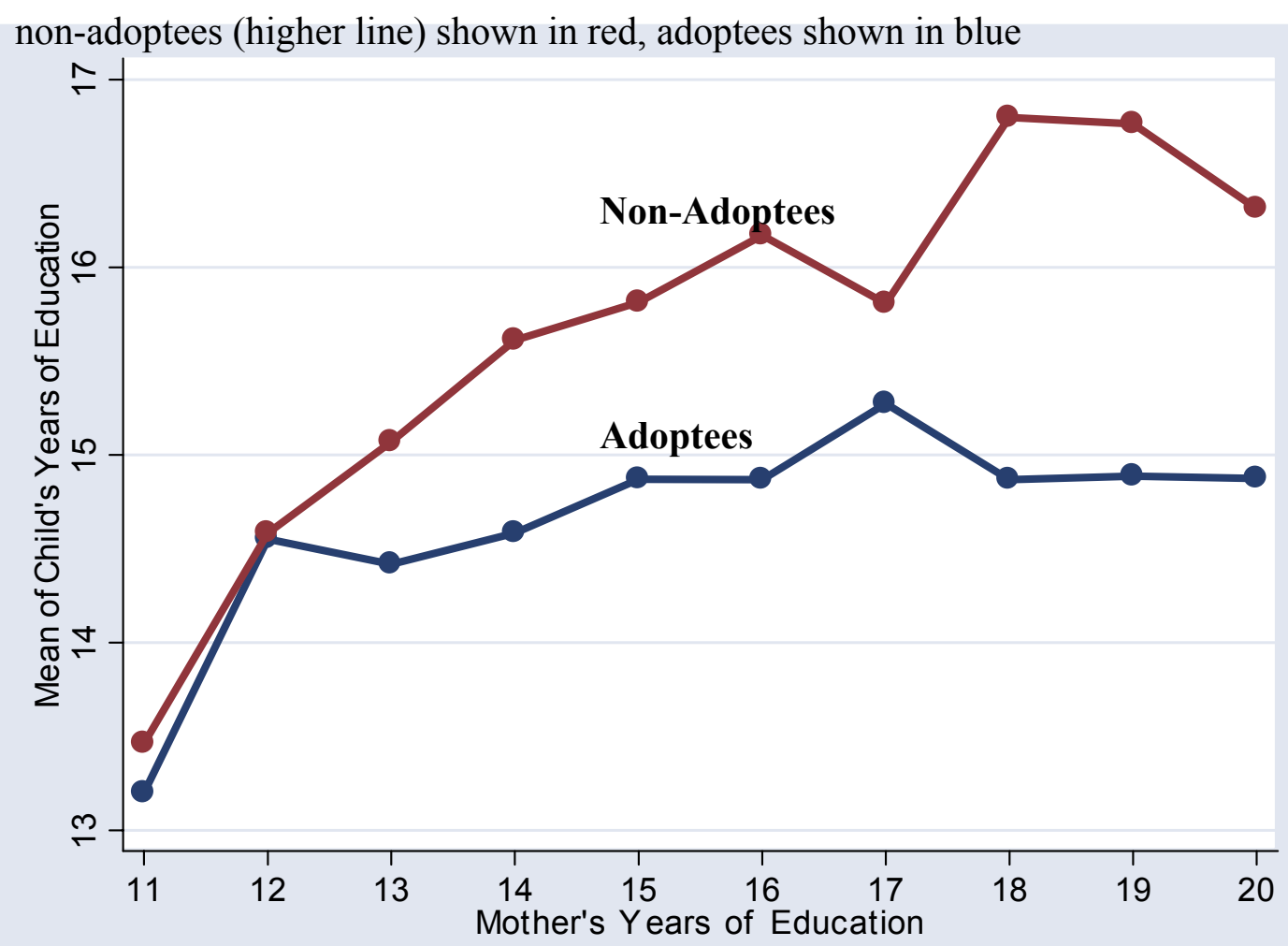

\section{Sample Sizes in Above Graph}

\begin{tabular}{rrrr}
\hline \hline $\begin{array}{r}\text { Mother's } \\
\text { Education }\end{array}$ & $\begin{array}{r}\text { Non- } \\
\text { Adoptees }\end{array}$ & Adoptees & $\begin{array}{r}\text { P Value for } \\
\text { Diff In Mean } \\
\text { Outcomes }\end{array}$ \\
11 & 13 & 11 & 0.94 \\
12 & 259 & 315 & 0.91 \\
13 & 93 & 111 & 0.17 \\
14 & 131 & 175 & 0.00 \\
15 & 85 & 82 & 0.01 \\
16 & 330 & 434 & 0.00 \\
17 & 71 & 85 & 0.07 \\
18 & 119 & 171 & 0.00 \\
19 & 56 & 61 & 0.00 \\
20 & 50 & 79 & 0.00 \\
\hline \hline
\end{tabular}




\section{Figure 3: Mean of Child's Family Income By Parent's Income At Adoption}

non-adoptees (higher line) shown in red, adoptees shown in blue

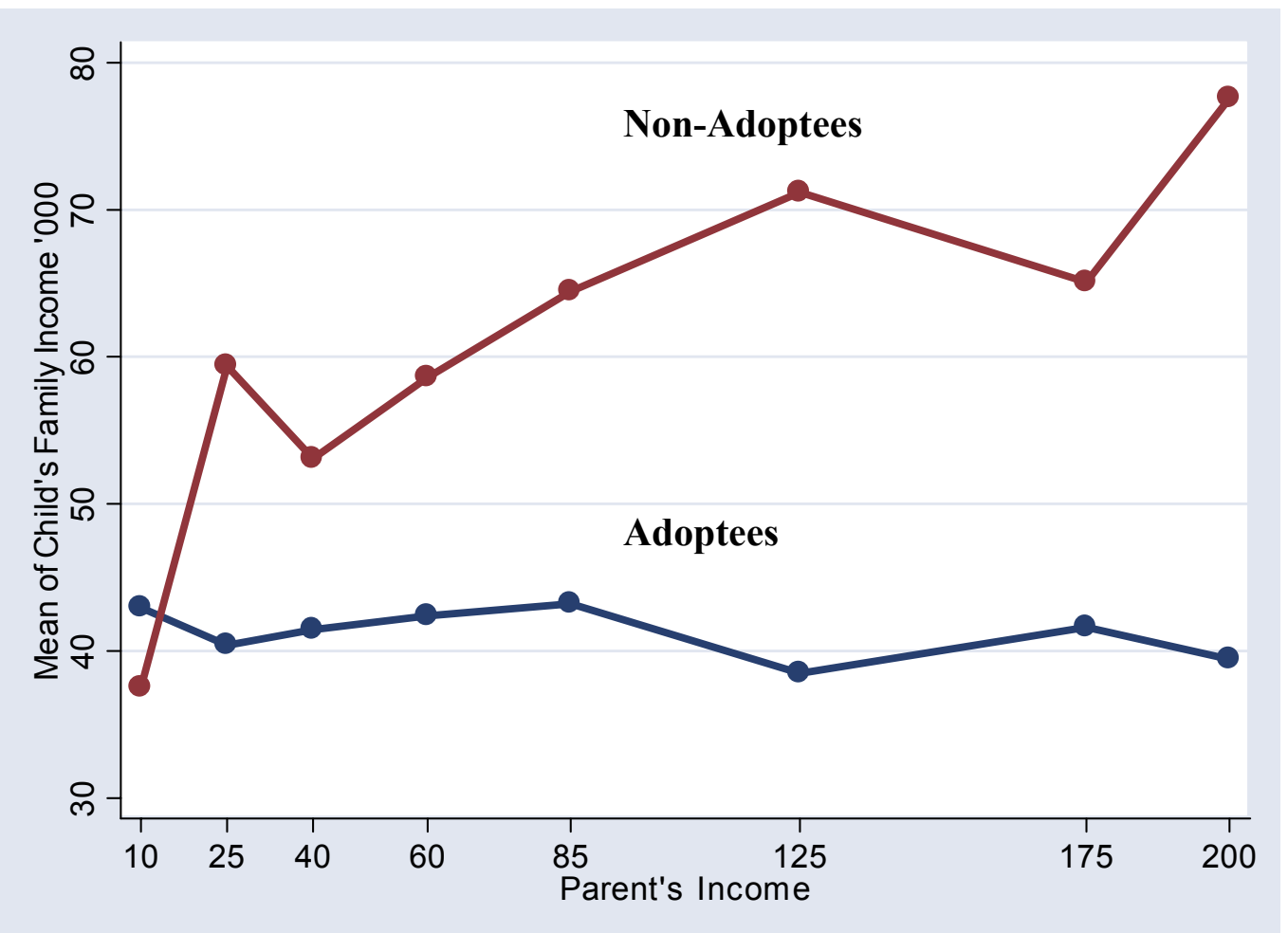

Sample Sizes in Above Graph

\begin{tabular}{lrrrrrrrr}
\hline \hline & 10 & 25 & 40 & 60 & 85 & 125 & 175 & 200 \\
Parent's Income & & & & & & & & \\
N .. Non-adoptees & 22 & 86 & 236 & 275 & 275 & 166 & 65 & 37 \\
N..Adoptees & 46 & 87 & 289 & 343 & 328 & 192 & 71 & 44 \\
P Value for Diff In & 0.56 & 0.00 & 0.00 & 0.00 & 0.00 & 0.00 & 0.00 & 0.00 \\
Outcomes & & & & & & & & \\
\hline \hline
\end{tabular}




\section{Figure 4: Comparison of Coefficient of Transmission from Parent to Child}

Graph shows coefficient from a regression of child's outcome on mother's outcome for adoptees and non-adoptees in the sample.

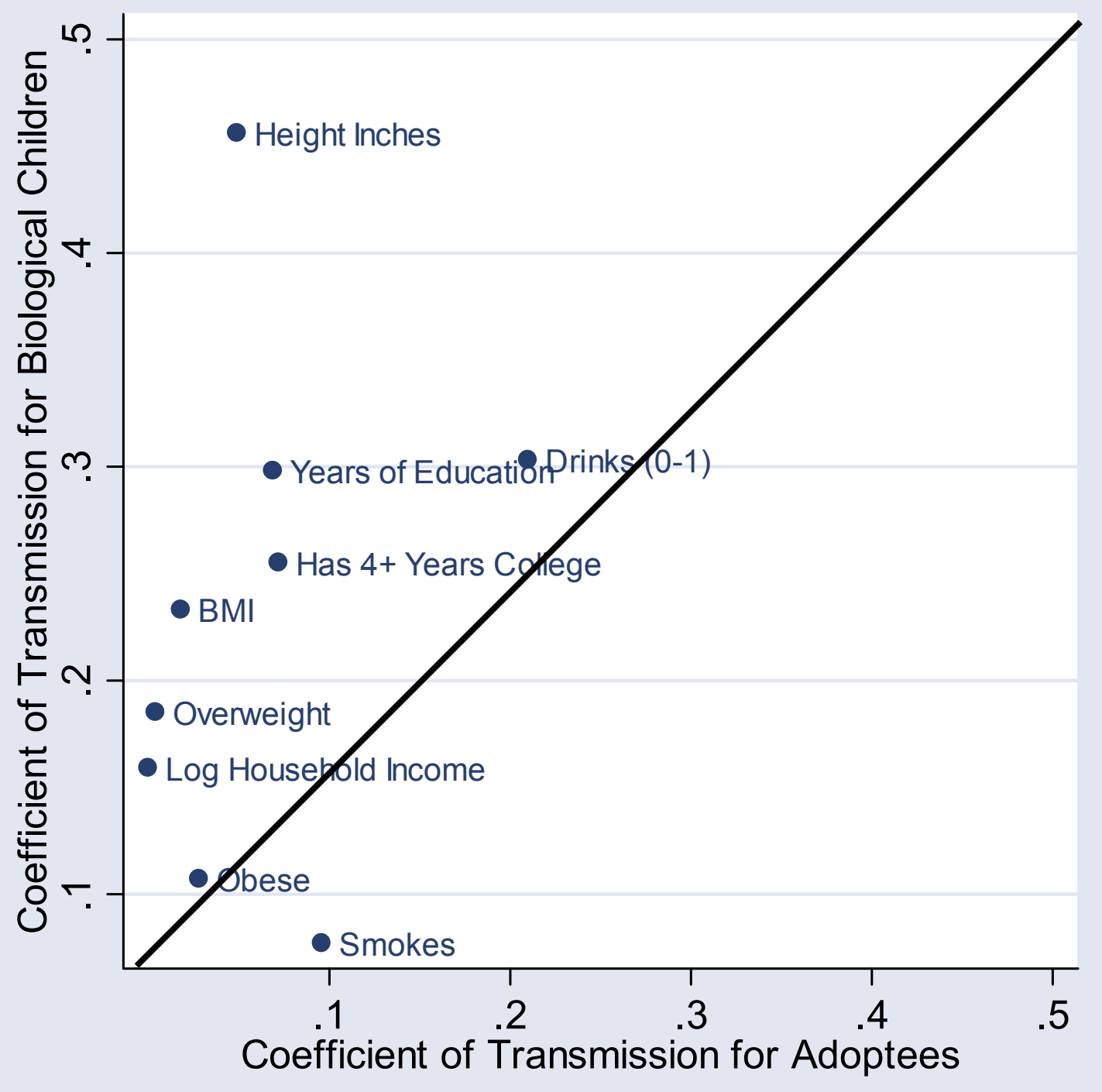




\section{Figure 5: Comparison of Percent of Variation Explained By Parental Characteristics for Each of Child Outcomes}

Graph shows R-squared from a regression of child's outcome on mother's and father's education, college status, smoking and drinking status, number of children, family income, height, weight, obesity and overweight status

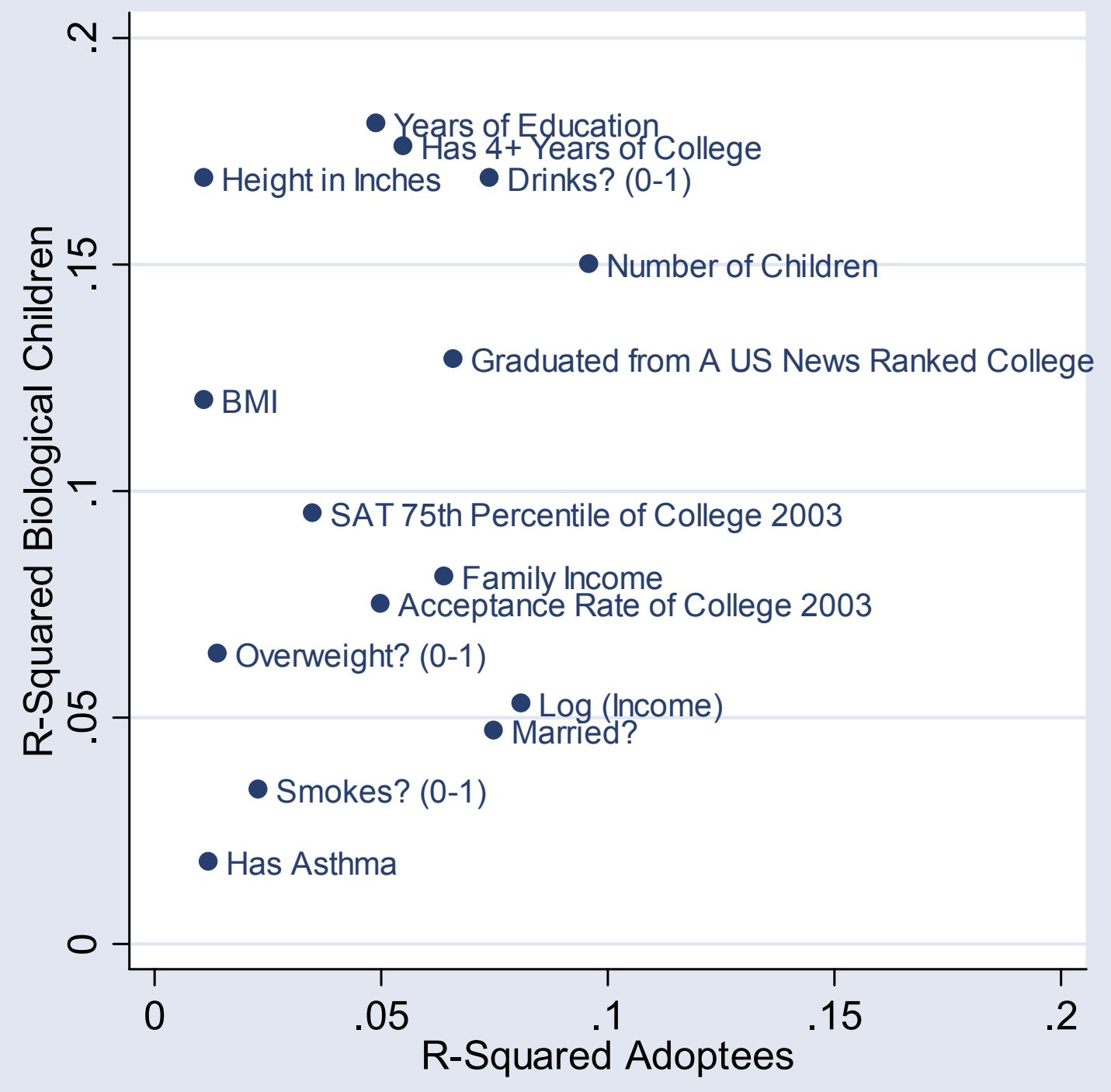

